\title{
Synaptic Regulator $\alpha$-Synuclein in Dopaminergic Fibers Is Essentially Required for the Maintenance of Subependymal Neural Stem Cells
}

\author{
(ㄷA Ana Perez-Villalba, ${ }^{1,2,3}$ M. Salomé Sirerol-Piquer, ${ }^{1,2,3}$ Germán Belenguer, ${ }^{1,2,3}$ Raúl Soriano-Cantón, ${ }^{1,2,3}$

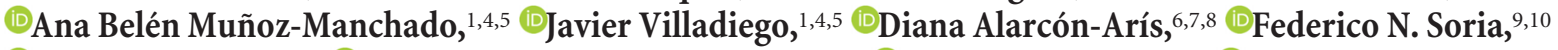 \\ ¿Benjamin Dehay, ${ }^{9,10}$ @Erwan Bezard, ${ }^{9,10}$ Miquel Vila, ${ }^{1,11,12 ~ @ A n a l i ́ a ~ B o r t o l o z z i, ~}{ }^{6,7,8}$ @Juan José Toledo-Aral, ${ }^{1,4,5}$ \\ Francisco Pérez-Sánchez, ${ }^{1,2,3}$ and $\odot$ Isabel Fariñas ${ }^{1,2,3}$ \\ ${ }^{1}$ Centro de Investigación Biomédica en Red de Enfermedades Neurodegenerativas, ISCIII, 28029 Madrid, Spain, ${ }^{2}$ Departamento de Biología Celular, \\ Biología Funcional y Antropología Física and ${ }^{3}$ Estructura de Recerca Interdisciplinar en Biotecnologia i Biomedicina, Universidad de Valencia, 46100 \\ Burjassot, Spain, ${ }^{4}$ Departamento de Fisiología Médica y Biofísica and ${ }^{5}$ Instituto de Biomedicina de Sevilla, Hospital Universitario Virgen del Rocío/CSIC/ \\ Universidad de Sevilla, 41013 Sevilla, Spain, ${ }^{6}$ Department of Neurochemistry and Neuropharmacology, IIBB-CSIC and ${ }^{7}$ Institut d'Investigacions \\ Biomèdiques August Pi i Sunyer, 08036 Barcelona, Spain, ${ }^{8}$ Centro de Investigación Biomédica en Red de Salud Mental, ISCIII, 28029 Madrid, Spain, \\ ${ }^{9}$ Université de Bordeaux, Institut des Maladies Neurodégénératives, Unité Mixte de Recherche 5293 and ${ }^{10}$ Centre National de la Recherche Scientifique, \\ Institut des Maladies Neurodégénératives, Unité Mixte de Recherche 5293, 33076 Bordeaux, France, ${ }^{11}$ Neurodegenerative Diseases Research Group, Vall \\ d'Hebron Research Institute, Autonomous University of Barcelona, 08035, Barcelona, Spain, and ${ }^{12}$ Catalan Institution for Research and Advanced Studies, \\ 08010 Barcelona, Spain
}

Synaptic protein $\alpha$-synuclein ( $\alpha$-SYN) modulates neurotransmission in a complex and poorly understood manner and aggregates in the cytoplasm of degenerating neurons in Parkinson's disease. Here, we report that $\alpha$-SYN present in dopaminergic nigral afferents is essential for the normal cycling and maintenance of neural stem cells (NSCs) in the brain subependymal zone of adult male and female mice. We also show that premature senescence of adult NSCs into non-neurogenic astrocytes in mice lacking $\alpha$-SYN resembles the effects of dopaminergic fiber degeneration resulting from chronic exposure to 1-methyl-4-phenyl-1,2,3,6-tetra-hydropyridine or intranigral inoculation of aggregated toxic $\alpha$-SYN. Interestingly, NSC loss in $\alpha$-SYN-deficient mice can be prevented by viral delivery of human $\alpha$-SYN into their sustantia nigra or by treatment with L-DOPA, suggesting that $\alpha$-SYN regulates dopamine availability to NSCs. Our data indicate that $\alpha$-SYN, present in dopaminergic nerve terminals supplying the subependymal zone, acts as a niche component to sustain the neurogenic potential of adult NSCs and identify $\alpha$-SYN and DA as potential targets to ameliorate neurogenic defects in the aging and diseased brain.

Key words: adult neurogenesis; niche biology; parkinsonism; Snca knock-out; stemness

Significance Statement

We report an essential role for the protein $\alpha$-synuclein present in dopaminergic nigral afferents in the regulation of adult neural stem cell maintenance, identifying the first synaptic regulator with an implication in stem cell niche biology. Although the exact role of $\alpha$-synuclein in neural transmission is not completely clear, our results indicate that it is required for stemness and the preservation of neurogenic potential in concert with dopamine.

\section{Introduction}

The subependymal zone (SEZ), located in the lateral ventricle walls, is the largest neurogenic niche of the rodent adult brain and continually provides local-circuitry neurons to the olfactory bulb (OB) (Chaker et al., 2016). SEZ neurogenesis is supported by a population of neural stem cells (NSCs; also called B1 cells) that 
can be recognized by expression of astrocytic markers GFAP or glutamate-aspartate transporter (GLAST) together with stemnessassociated transcription factor Sox2. B1 cells exhibit a radial morphology with a primary cilium-containing apical process that protrudes into the ventricle to contact the CSF (Mirzadeh et al., 2008). They generate transcription factor Ascl1-positive transitamplifying progenitor (TAP) cells that mainly differentiate into fate-specified PSA-NCAM ${ }^{+} / \beta$ III-tubulin ${ }^{+} /$doublecortin $^{+}$neuroblasts, which migrate following the rostral migratory stream (RMS) to the OB, where they become granular and periglomerular interneurons involved in odor discrimination (Chaker et al., 2016; Lledo and Valley, 2016).

The SEZ microenvironment sustains NSC maintenance and contributes to balance NSC self-renewal and differentiation. Although neurotransmission has been traditionally associated with signaling between neurons, innervation is emerging as one key component of the SEZ microenvironment. The subependymal niche is directly supplied by fibers of different origins, including dopaminergic (DAergic) afferents from the substantia nigra (SN), serotoninergic fibers from raphe nuclei and cholinergic axons from striatal neurons (for review, see Berg et al., 2013; Bjornsson et al., 2015). Selective lesion of DAergic fibers results in reduced proliferation of TAP cells in the SEZ of rodents and primates (Baker et al., 1993; Coronas et al., 2004; Höglinger et al., 2004; Van Kampen et al., 2004; Yamada et al., 2004; Freundlieb et al., 2006; Winner et al., 2006, 2009; O'Keeffe et al., 2009; Kim et al., 2010; Lao et al., 2013). Intriguingly, inhibiting actions of longterm DA receptor stimulation have also been reported (Kippin et al., 2005), suggesting that DA effects on specific cell types of the neurogenic lineage require further analysis (Berg et al., 2013).

Despite the increasing interest in how innervation regulates adult neurogenesis, the potential role of synaptic regulators of neurotransmitter release also remains largely unexplored. $\alpha$-Synuclein $(\alpha-\mathrm{SYN})$ is a 140 amino acid natively unstructured brain protein particularly enriched in axon terminals, where it associates with synaptic vesicles and regulates different forms of synaptic plasticity through mechanisms that have not been completely elucidated (Venda et al., 2010; Cheng et al., 2011; Burré, 2015). $\alpha$-SYN is also the main constituent of the intraneuronal pathological aggregates, known as Lewy bodies (LBs), characteristically found in degenerating DAergic nigral neurons of patients with Parkinson's disease (PD) (Poewe et al., 2017). Missense mutations in the SNCA/PARK1 gene encoding aggregation-prone $\alpha$-SYN, as well as $S N C A$ gene amplifications resulting in higher protein levels, cause a familial form of PD indicating its causal role in the disease (Poewe et al., 2017).

(Programa Prometeo) to I.F.; European Regional Development Fund; and European Union (E.U.) to A.B. R.S.-C. and G.B. received Spanish Ministerio de Educación FPU predoctoral fellowships. Work in the I.F. laboratory is supported by Fundación Botín-Banco Santander. We thank Eva Porlan, Jose Manuel Morante-Redolat, and Sacri R. Ferrón for helpful discussions and scientific advice; Ma Ángeles Asensi for advice and help with the high-performance liquid chromatography coupled to tandem mass spectrometry analysis; Inmaculada Noguera and Ma José Palop for mouse care and veterinary advice; Servicio (entral de Soporte a la Investigación Experimental (Universidad de Valencia); $\mathrm{Ma}$ Teresa Rávena for statistical advice; Ma Ángeles Marqués-Torrejón for help with the caspase-3 experiment; Brain Bank GIE NeuroCEB (BRIF 0033-00011), funded by the patients' associations France Alzheimer, France Parkinson, ARSEP, and "Connaître les Syndromes Cérébelleux," the New York Brain Bank at Columbia University, and the University of Barcelona Brain Bank, for providing human postmortem samples; and the Michael J. Fox Foundation for the kind donation of the AAV 5 carrying the human $\alpha$-SYN.

The authors declare no competing financial interests.

Correspondence should be addressed to either Dr. Isabel Fariñas or Dr. Francisco Pérez-Sánchez, Departamento de Biología Celular, Universidad de Valencia, Doctor Moliner 50,46100 Burjassot, Spain. E-mail: isabel.farinas@uv.es or pacops@uv.es.

DOI:10.1523/JNEUROSCI.2276-17.2017

Copyright $\odot 2018$ the authors $\quad 0270-6474 / 18 / 380815-12 \$ 15.00 / 0$
Here, we have analyzed the role of $\alpha$-SYN in adult olfactory neurogenesis. Young mice lacking $\alpha$-SYN exhibit reductions in newly generated OB neurons and in NSC activation that are characteristically found in aged wild-type mice. At the cellular level, we show that $\alpha$-SYN is not expressed by SEZ resident cells but is present in afferents supplying the SEZ, including DAergic fibers. Acting as a niche factor, $\alpha$-SYN is essentially required for maintaining normal numbers of NSCs in an undifferentiated and cycling state. Interestingly, neurogenic defects observed in mutant mice mimic those found in toxic models of parkinsonism. The action of $\alpha$-SYN appears related to DA innervation as adenovirusmediated reintroduction of $\alpha$-SYN into SN neurons and DAergic pharmacotherapy rescues the mutant phenotype. Our work describes a direct effect of $\alpha$-SYN in DAergic fibers on the maintenance of adult NSCs.

\section{Materials and Methods}

\section{Animals and in vivo treatments}

Generation of Snca mutant mice and their genotyping by PCR have been described previously (Abeliovich et al., 2000). All animals were gender group-housed with standard pelleted food and tap water ad libitum. Animal handling and all experimental procedures were performed in accordance to European Union 86/609/EEC and Spanish RD1201/2005 guidelines, following protocols approved by the ethics committee on experimental research of corresponding institutions. For intranigral viral injections, $1 \mu \mathrm{l}$ adeno-associated viral serotype 5 vectors (AAV5) $(1.0 \times$ $10^{13} \mathrm{vg} / \mathrm{ml}$ ) carrying the human $\alpha$-SYN under the control of a chicken $\beta$-actin (CBA) promoter (AAV5-CBA-h- $\alpha$-SYN) was unilaterally injected into a region immediately above the SNpc (using stererotactic coordinates $-2.9 \mathrm{~mm}$ anteroposterior, $1.3 \mathrm{~mm}$ lateral, and $-4.5 \mathrm{~mm}$ dorsoventral from bregma) of 2 month mice of either sex at a rate of $0.4 \mu \mathrm{l} / \mathrm{min}$ using a $10 \mu \mathrm{l}$ Hamilton syringe fitted with a glass capillary (outer diameter of $250 \mu \mathrm{m}$ ), and the needle was left in place for an additional $5 \mathrm{~min}$ period before it was slowly retracted. The same procedure was used for intranigral inoculations of $2 \mu$ l of either LB fractions, containing toxic fibrillary $\alpha$-SYN, or non-LB fractions, containing soluble or finely granular $\alpha$-SYN (Recasens et al., 2014). For chronic treatment with 1-methyl-4-phenyl-1,2,3,6-tetra-hydropyridine (MPTP) (Sigma-Aldrich), mice of either sex were injected with three subcutaneous injections of $20 \mathrm{mg} / \mathrm{kg}$ of body weight MPTP per week during 3 months. For L-DOPA treatment, mice of either sex were given benserazide-hydrochloride (Sigma-Aldrich; $5 \mathrm{mg} / \mathrm{kg}$ of body weight) to block peripheral decarboxylation of the L-DOPA followed, 30 min later, by L-DOPA methyl ester (Sigma-Aldrich) at a dose of $20 \mathrm{mg} / \mathrm{kg}$ body weight in saline solution $(0.9 \% \mathrm{NaCl})$ with ascorbic acid at $0.5 \mathrm{mg} / \mathrm{ml}$. The drugs were administered as a $200 \mu \mathrm{l}$-volume intraperitoneal injection per day, 3 consecutive days and control animals were injected with an equivalent volume of saline solution. BrdU (Sigma-Aldrich; $10 \mathrm{mg} / \mathrm{ml}$ in saline) was administered by intraperitoneal injection at $50 \mathrm{mg} / \mathrm{kg}$ body weight using saline as vehicle. Some animals were injected once and perfused $1 \mathrm{~h}$ after the injection and some animals were injected seven times in a $12 \mathrm{~h}$ period, with one injection every $2 \mathrm{~h}$, and perfused $30 \mathrm{~d}$ after the last injection.

\section{Behavioral tests}

Olfactory habituation-dishabituation test. The two synthetic odorants used in our habituation-dishabituation test, geraniol (3,7-dimethyl-2,6octadien-1-ol) and citralva (geranonitrile, 3,7-dimethyl-2,6-octadien-1nitrile), were kindly supplied by Ventós dealer of International Flavors and Fragrances. Male mice were placed in a $22.5 \mathrm{~cm} \times 22.5 \mathrm{~cm}$ open Plexiglas box with solid light green walls and $\sim 1 \mathrm{~cm}$ of wooden chips bedding on the floor. After $3 \mathrm{~min}$ of free exploration, a cotton stick soaked in mineral oil was introduced into the box through a hole of $1 \mathrm{~cm}$ of diameter located at $8 \mathrm{~cm}$ above the box ground and at $11.2 \mathrm{~cm}$ from the lateral corner of the box. The stick protruded from the wall $\sim 3 \mathrm{~cm}$. The stick was held in place for $1 \mathrm{~min}$ and thereafter it was substituted by a series of 5 consecutive fresh cotton sticks soaked also in nonodorant mineral oil to produce a habituation to the novel object and the entrance 
and exit of cotton sticks in and out the box, and also serving as a control between genotypes in the response to nonodorant stimuli. After 6 trials of a nonodorant stimulus, mice were exposed to 6 subsequent trials of geraniol and 6 trials of citralva, both diluted (1:20) in mineral oil. We used a new stick every time and used sticks were left in a sealed container, so the remaining odor was no longer available to mice. The exposure of the odorant stimuli was of the same length and characteristics than the mineral oil exposure. We used a digital video system to record every test and the olfactory exploration of mice was evaluated. Actions recorded as olfactory exploration included smelling, sniffing, and heading the nose toward the cotton stick either with physical contact with the cotton or at a close distance $(2-3 \mathrm{~cm})$. For evaluation purposes, we used tracking software (Smart Junior, Panlab S.L., Harvard Apparatus) that divided the smelling box image into two concentric and rectangular areas that delimited: a close area from the stick to the border, $3 \mathrm{~cm}$ away, and the rest of the box. Those divisions were exactly the same for every experimental animal. Any kind of exploratory behavior (e.g., sniffing at a close distance) directed to the odor stimulus and confined inside this area was measured as a sign of specific olfactory exploration. After each test, the olfactory exploration box was thoroughly wiped clean with $5 \%$ alcohol and dried. We used a novel group of mice for every experiment. Details and analyses of olfactory behavior tests performed here are described in detail (Pérez-Villalba et al., 2015).

Open field test. General motor activity was examined in a square $45(\mathrm{~W}) \times 45(\mathrm{D}) \times 40(\mathrm{H}) \mathrm{cm}$ open field (Panlab S.L., Harvard Apparatus). The open field was indirectly and homogeneously illuminated. Male mice were nicely placed always on the inferior left corner of the open field and observed for $20 \mathrm{~min}$. After each test, the open field was thoroughly wiped clean with $5 \%$ alcohol and dried. For evaluation purposes, the tracking software (Smart Junior, Panlab S.L., Harvard Apparatus) automatically measured the total distance traveled and mean speed of every experimental subject.

Context conditioning. Context conditioning was produced by the association of a conditioning stimulus, such as context, with a single $0.7 \mathrm{~mA}$ electric foot shock during $2 \mathrm{~s}$ (unconditioning stimulus). The conditioning context consisted on a $20 \mathrm{~cm}$ (width) $\times 20 \mathrm{~cm}$ (depth) $\times 25 \mathrm{~cm}$ (height) aluminum lightly illuminated box with three metal walls, a methacrylate front door, and a stainless-steel grid on the floor (Smart Junior, Panlab S.L., Harvard Apparatus). Each male mouse was placed in the conditioning box, received one foot shock after $3 \mathrm{~min}$, and was taken out of the cage $2 \mathrm{~min}$ later. This protocol has been shown to be effective in reproducing an associative learning between the context (in the forms of a conditioning stimulus) and the shock (the unconditioning stimulus) (Milanovic et al., 1998). To assess short- and long-term memory of context fear conditioning, mice were tested 1 or $24 \mathrm{~h}$ later in the same conditioning box, in the absence of any foot shock. In both cases, freezing behavior during $5 \mathrm{~min}$ was evaluated. Freezing conditioning response was defined as the cessation of all movement with the exception of respiration-related movement (Fanselow, 1980), usually performed in a crouching posture, lasting at least $2 \mathrm{~s}$, and it was shown to be specific and not generalized to other contexts as mice did not freeze significantly when placed in an alternative context. The alternative context, to which the mice were exposed also for 5 min either 1 or $24 \mathrm{~h}$ after the conditioning, consisted of a different conditioning box in which the walls were covered with color wrapping paper, the stainless-steel grid on the floor was substituted by wooden chips bedding, the illumination came from a direct light at the ceiling of the box and which was impregnated with pine scent. Mice were randomly assigned to pass first through the learning test in the conditioning box and then the alternative context, or the opposite.

Sucrose preference test. Male mice were single-housed and allowed to drink from two different bottles in their home cage. One bottle contained regular tap water, and the other bottle had $3 \%$ sucrose diluted in the same water. Both bottles were measured and changed daily (3\% sucrose was prepared fresh every day); and after $3 \mathrm{~d}$ of habituation, the rate of sucrose preference was calculated by dividing consumption of sweet water by consumption of tap water.

Elevated plus maze. The elevated plus maze has been described as a simple method for assessing anxiety responses of rodents (Pellow et al., 1985), as it challenges mouse proclivity toward dark, enclosed spaces (approach) and an unconditioned fear of heights/open spaces (avoidance) (Barnett and Smart, 1975). The elevated plus maze was a graypainted Plexiglas apparatus with four $30-\mathrm{cm}$-long and 5-cm-wide arms (two open and two enclosed by $15.25 \mathrm{~cm}$ high walls). Each arm of the maze is attached to sturdy metal legs such that it is elevated $40 \mathrm{~cm}$ off the ground. In this task, the open arms are normally avoided and rodents spend the majority of the time in the closed arms of the maze. Each male mouse was gently left in the middle of the elevated plus maze facing always the same arm. The task was recorded during single 5 min testing sessions, and the different behaviors, such as time spent and number of entries in the open arms, displayed by each animal were measured by tracking software (Smart Junior, Panlab S.L., Harvard Apparatus).

\section{Determination of dopamine and metabolites}

Whole dissected striata were frozen in liquid nitrogen $\left(\mathrm{N}_{2}\right)$ and stored at $-80^{\circ} \mathrm{C}$ until use. Frozen striatal samples were homogenized in $500 \mu \mathrm{l}$ of $4 \%$ perchloric acid and then centrifuged for $10 \mathrm{~min}$ at $10,000 \times g\left(4^{\circ} \mathrm{C}\right)$. The concentration of DA in the supernatants was determined by highperformance liquid chromatography coupled to tandem mass spectrometry. The chromatographic system consisted of a Micromass Quatro triple-quadrupole mass spectrometer equipped with a $\mathrm{Z}$-spray electrospray ionization source with a LC-10A (Shimadzu) coupled to the MassLynx software version 4.1 for data acquisition and processing. Samples were analyzed by reversed-phase high-performance liquid chromatography (HPLC) with a $\mathrm{C}_{18}$ Mediterranea SEA column (Teknokroma) $(5.0 \times 0.21 \mathrm{~cm})$ with $3 \mu \mathrm{m}$ particle size. In all cases, $20 \mu \mathrm{l}$ of the extract was injected onto the analytical column. The mobile phase consisted of the following gradient system $(\mathrm{min} / \% \mathrm{~A} / \% \mathrm{~B})(\mathrm{A}, 0.5 \%$ formic acid; B, methanol): $2 / 95 / 5,5 / 5 / 95,13 / 5 / 95,13.10 / 95 / 5$, and 30/95/5. The flow rate was set at $0.2 \mathrm{ml} / \mathrm{min}$. The ESI source values were as follows: capillary voltage, $3 \mathrm{kV}$; extractor, $2 \mathrm{~V}$; RF lens, $0.5 \mathrm{~V}$; source temperature, $120^{\circ} \mathrm{C}$; desolvation temperature, $350^{\circ} \mathrm{C}$; desolvation gas (nitrogen, $99.9 \% \mathrm{pu}-$ rity) flow $500 \mathrm{~L} / \mathrm{h}$; cone (gas flow): $30 \mathrm{~L} / \mathrm{h}$. The analyzer parameters were LM resolution 13, HM resolution 13, and ion energy 1 for MS1 and MS2; multiplier, $650 \mathrm{~V}$; collision gas argon; interchannel delay $0.02 \mathrm{~s}$; interscan delay $0.05 \mathrm{~s}$. Analyzed compounds were identified by retention time and spectra matching of standards $(1 \mathrm{~mm})$, determining the transition $(\mathrm{m} / \mathrm{z})$, cone energy $(\mathrm{V})$, and collision energy $(\mathrm{eV})$ for each as follows: $154.2 \rightarrow 137.2$, 15,15 for DA; $183.4 \rightarrow 137.1,15,10$ for HVA and $169.4 \rightarrow 123.3,15,10$ for DOPAC. Calibration curves were obtained using 6 point standards (from 0.01 to $100 \mu \mathrm{M}$ ) (Sigma-Aldrich) for each compound. The amounts of total metabolites were calculated based on the weight of the dissected striatum, and the results were expressed as nanograms per gram of tissue.

\section{Immunohistochemistry and stereology}

Animals of either sex were deeply anesthetized and transcardially perfused with $4 \%$ PFA in $0.1 \mathrm{M}$ phosphate buffer, $\mathrm{pH} 7.4$, and brains processed for vibratome sectioning at $40 \mu \mathrm{m}$ or dissected to obtain whole mounts of the SEZ as described. Sections were blocked in phosphate buffer containing 10\% FBS and 0.2\% Triton X-100. For BrdU immunodetection, sections were first treated with $2 \mathrm{~N} \mathrm{HCl}$ for $17 \mathrm{~min}$ at $37^{\circ} \mathrm{C}$ followed by several phosphate buffer rinses. After blocking, sections were incubated in rabbit antibodies to $\alpha$-SYN (1:1200, AbD Serotec), Ki67 (1:150, Abcam), $\beta$-catenin (1:100, Cell Signaling Technology), TH (1: 600 , Pel-Freez), $\beta$-III-tubulin (1:175, Sigma-Aldrich), S100 $\beta$ (1:100, Dako), or epidermal growth factor receptor (EGFR) (1:100, Cell Signaling Technology), mouse antibodies to $S 100 \beta$ (1:500, Sigma-Aldrich), $\beta$-III-tubulin (1:200, Covance), Ki67 (1:50, Novocastra), $\alpha$-SYN (1:1200, BD Biosciences), Ascl1 (1:150, BD Biosciences), Neu-N (1:100, Millipore), TH (1:500, Sigma-Aldrich), or human $\alpha$-SYN (1:1350, Abcam, ab27766), rat antibodies to BrdU (1:800, Abcam), goat antibodies to Sox2 (1:150, R\&D Systems), $\gamma$-tubulin (1:150, Santa Cruz Biotechnology), and chicken antibodies to GFAP (1:800, Millipore), alone or in different combinations for $24-48 \mathrm{~h}$ at $4^{\circ} \mathrm{C}$. After several washes, the sections were incubated for $1 \mathrm{~h}$ at room temperature with appropriate fluorescently labeled secondary antibodies: Alexa-555-conjugated goat anti-mouse, Alexa-488-goat anti-rabbit and anti-mouse, Alexa-647-goat anti-rabbit, and Alexa-488-donkey anti-chicken at 1:500 (Invitrogen), or 
Cy3-donkey anti-chicken and Cy3-goat anti-mouse (1:1000, Jackson ImmunoResearch Laboratories). DAPI ( $1 \mu \mathrm{g} / \mathrm{ml}, 5 \mathrm{~min}$, Sigma-Aldrich) was used for counterstaining. Immunostained sections and whole mounts were photographed using a confocal laser scanning microscope FV-10i (Olympus), and separate images were taken with restrictive filters of excitation in each fluorescent channel every $1 \mu \mathrm{m}$, and the tracing of individual cells across the tissue and subsequent quantitative analyses were performed on high-resolution image stacks. Volumes of OBs were calculated using a point-counting grid of an associated area following the Cavalieri method in equivalent sections stained with cresyl violet. Pinwheels and B1 cells were quantified in randomly chosen fields, covering equivalent anterodorsal or posterodorsal regions of immunostained SEZ whole mounts. At least 20 fields (at $100 \times$ magnification) per region were quantified in each subject.

\section{SEZ dissociation and flow cytometry analysis}

The SEZs from 2- to 3-month-old mice of either sex were microdissected and dissociated following recommendations of the Neural Tissue Dissociation Kit (Miltenyi) with minimal modifications. Briefly, SEZs were minced and digested in a solution containing $0.025 \%$ trypsin-EDTA (Invitrogen) using the gentleMACS Octo Dissociator. To isolate striatal astrocytes, the striatum close to the SEZ was collected and processed in parallel. The cell suspension was diluted with $3 \mathrm{ml}$ of washing medium ( $0.6 \%$ glucose, $0.1 \% \mathrm{NaHCO}_{3}, 5 \mathrm{~mm}$ HEPES, $2 \mathrm{~mm}$ L-glutamine, $0.4 \%$ BSA, $1 \times$ antibiotic/antimicotic in DMEM/F-12), filtered through a $40 \mu \mathrm{m}$ nylon filter, and then centrifuged $(300 \times g, 10 \mathrm{~min})$. The Dead Cell Removal Kit (Miltenyi Biotec) was used to remove dead cells from cell samples, following the manufacturer's instructions. Briefly, magnetic-activated cell sorting was performed on the dissociated cells, using magnetic bead-bound antibodies against apoptotic and necrotic cells. Finally, the eluted living fraction was pelleted $(300 \times g, 10 \mathrm{~min})$, resuspended in $100 \mu \mathrm{m}$ blocking buffer (Ca and Mg-free HBSS, $10 \mathrm{~mm}$ HEPES, 2 mM EDTA, $0.1 \%$ glucose, $0.5 \%$ BSA), and incubated with combinations of the following antibodies: CD45-BUV395 (1:200, BD Biosciences), 04-Biotin (1:30, Miltenyi), CD31-BUV395 (1:100, BD Biosciences), Ter119-BUV395 (1:200, BD Biosciences), streptavidin-Alexa350 (1: 200, Invitrogen), EGF-Alexa488 (1:300, Invitrogen), CD120b-PE (1:20, BD Biosciences), CD24-PerCP-Cy5.5 (1:300, BD Biosciences), GLASTAPC (1:20, Miltenyi), PSA-NCAM-APC (1:50, Miltenyi) and CD9Vio770 (1:20, Miltenyi), and DAPI $50(\mu \mathrm{g} / \mathrm{ml})(1: 500$, Sigma $)$ at $4^{\circ} \mathrm{C}$ for $30 \mathrm{~min}$. After washing with $1 \mathrm{ml}$ of blocking buffer, labeled samples were centrifuged $\left(300 \times \mathrm{g}, 10 \mathrm{~min}\right.$, at $\left.4^{\circ} \mathrm{C}\right)$ and resuspended in $0.5 \mathrm{ml}$ of blocking buffer. Cells were analyzed using a LSR-Fortessa (BD Biosciences) with $350,488,561$ and 640 lasers.

\section{Statistics and data analysis}

All experiments were conducted double-blind to the genotype and treatment. All values are expressed as the mean \pm SEM of the indicated number $(n)$ of independent subjects. For HPLC experiments, values were normalized to the mean level of control group. Differences among means were analyzed using a two-tailed Student's t test, one or two-way ANOVA or, in the event of failure in normality test, by a Mann-Whitney $U$ test. For the analysis of context fear conditioning, the factors considered in the two-way-ANOVA were as follows: "context conditioning" and "genotype." In the two-way repeated-measures ANOVA measurements of odor habituation and odor sensitivity, the factors considered were "stick order" and "genotype." For the analysis of MPTP or L-DOPA experiments, the factors considered were "treatment" and "genotype." For the analyses of adenovirus insertion, the factors considered were "AAVsyn" and "genotype." When ANOVA showed significant group differences, pairwise comparisons were tested by Bonferroni's post hoc analysis. Statistical analyses were performed using SPSS version 24 (IBM) or Prism version 5 (GraphPad Software).

\section{Results}

Young adult Snca-null mice exhibit decayed olfactory behavior and neurogenesis

As an assessment of the potential implication of $\alpha$-SYN in adult neurogenesis, we evaluated olfactory discrimination in 2 month
Snca wild-type and mutant male mice (Abeliovich et al., 2000). To discard competing behaviors, such as exploration of novel stimuli and motivation, associative learning and memory, reward seeking, or anxiety, we first checked that mice did not differ in their performance in open-field, classical contextual conditioning, and sucrose preference tests, or in the elevated plus maze (Fig. 1a-d) (Abeliovich et al., 2000; Peña-Oliver et al., 2010, 2012, 2014). We then measured their capacity to perceive synthetic non emotional odorants using a threshold detection test (PerezVillalba et al., 2015). Each mouse was first presented with a series of six cotton swabs freshly soaked in mineral oil to habituate the animals to the sticks. Afterward, each mouse was exposed to cotton sticks impregnated with increasing concentrations of a scent diluted in mineral oil $(1: 160,1: 80,1: 40,1: 20$, or $1: 10)$ to determine the minimum concentration that triggered exploration. Both genotypes performed equally well in the detection test for geraniol, a sweet rose-like scent, and citralva, a lemon-like citrus odorant, and the threshold was set at 1:20 for both scents (data not shown).

Another group of mice were then tested in a classic olfactory discrimination test (Perez-Villalba et al., 2015). In brief, after six presentations of mineral oil-soaked swabs, animals were exposed to six successive presentations of geraniol, followed by a similar series of citralva. Habituation to the first odor and reaction (dishabituation) to the second one were quantitated as the time that the animal spent paying attention to and sniffing each stick. Wild-type mice actively explored geraniol in the first presentations, then habituated (i.e., interest declined over successive exposures), and exhibited renewed interest toward the new scent, but Snca mutant mice reacted more poorly than wild types to geraniol and did not appear to discriminate citralva (Fig. 1e). Reduced olfactory discrimination is characteristically found in aged mice (Maslov et al., 2004; Luo et al., 2006; Bouab et al., 2011; Rey et al., 2012). Remarkably, we found equally reduced activity in odor detection and discrimination in 12 month mice of the two genotypes (Fig. 1e). Together, the data indicated that lack of $\alpha$-SYN results in specific defects in olfactory discrimination that are prematurely displayed at young ages.

A connection between fine olfactory discrimination and adultborn $\mathrm{OB}$ neurons has been experimentally established (Lledo and Valley, 2016). The rate of olfactory neurogenesis can be determined by birth dating experiments in which the animals are injected with BrdU 4 weeks before death. Under these conditions, $\mathrm{BrdU}$ is detected only in those cells that retained it because they abandoned the cell cycle immediately after exposure to the nucleoside. In young Snca mutants, the densities of $\mathrm{BrdU}^{+}$cells (in cells $\times 10 / \mathrm{mm}^{3}: 21.3 \pm 5.7$ vs a wild-type value of $31.6 \pm 7.2, n=$ $4, p<0.05$; Fig. $1 f$ ) and of $\mathrm{BrdU}^{+}$cells, which were also positive for the neuronal differentiation marker NeuN (in cells $\times 10$ / $\mathrm{mm}^{3}: 6.4 \pm 1.0$ vs a wild-type value of $13.4 \pm 0.1, n=3, p<0.01$ ) were significantly reduced, indicating that $\alpha$-SYN is indeed required for adult neurogenesis.

During fetal development, expression of $\alpha$-SYN has been reported to increase concomitantly with neuronal differentiation (Zhong et al., 2010). Likewise, we could not detect $\alpha$-SYN in premigratory recently generated $\beta$-III-tubulin ${ }^{+}$neuroblasts in the SEZ or the posterior half of the RMS, but its levels increased progressively in neuroblasts as they matured and approached the OB (Fig. 2a). Despite the increasing presence of $\alpha$-SYN in maturing neuroblasts, their density $\left(22.9 \pm 1.5 \%\right.$ of DAPI in $\mathrm{Snca}^{+/+}$, $n=3$, vs $19.7 \pm 1.3 \%$ in $S n c a^{-1-}$ mice, $\left.n=4\right)$, spatial distribution along the rostrocaudal axis (data not shown), or survival $\left(18.1 \pm 2.0 \%\right.$ caspase $3^{+}$neuroblasts in Snca ${ }^{+/+}$vs $17.9 \pm 5.2$ in 


\section{$\square$ Snca $^{+/+} 2-\mathrm{m} \square$ Snca $^{-/-2-m}$}

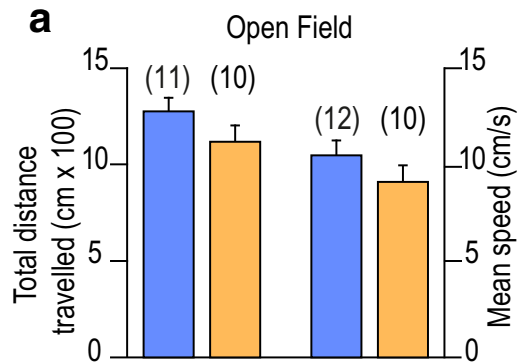

b Context Fear Conditioning
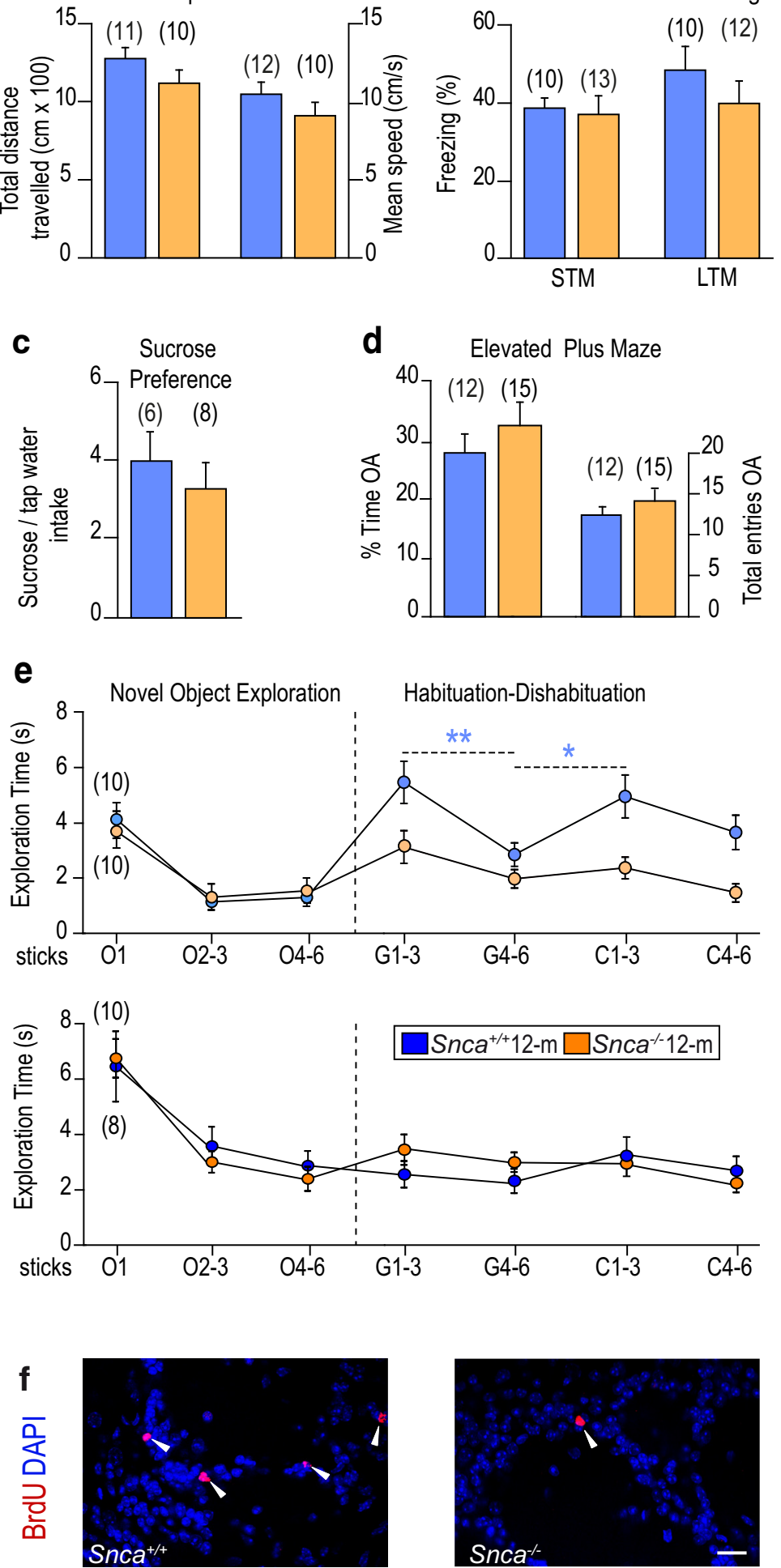

Figure 1. Snca-null mice exhibit deficits in olfaction and adult neurogenesis. Behavioral analysis of 2 month Snca wild-type $\left(\right.$ Snca $\left.{ }^{+/+}\right)$and mutant (Snca ${ }^{-/-}$) mice showing $(\boldsymbol{a})$ the total distance traveled (in centimeters $\times 100$ ) and the mean speed (in centimeters per second) in an open field test for locomotor activity; ( $\boldsymbol{b})$ the proportion of freezing time in context fear conditioning with short-term memory test (STM) and long-term memory test (LTM); (c) the sucrose to tap water intake ratio in a sucrose preference test; and $(\boldsymbol{d})$ the proportion of time spent and the total number of entries in the open arms $(0 \mathrm{~A})$ of an elevated plus maze. e, Olfactory habituation-dishabituation test of 2 month (above) and 12 month (below) mice of different genotypes. Exploration time (in seconds) of successive sticks soaked in mineral oil (0), geraniol (G), or citralva (C). No differences were observed in
Snca ${ }^{-/-}$mice, $n=3$ ) was unchanged by the mutation, indicating that $\alpha$-SYN does not play a distinct intrinsic role in neuroblasts.

\section{Synaptic $\alpha$-SYN in DA terminals} maintains stemness in the adult SEZ

We next considered the possibility that reduced production of newly generated $\mathrm{OB}$ neurons in Snca mutants could be the result of defects in NSC activity in the SEZ. Immunocytochemical stainings with antibodies to $\alpha$-SYN and to $\beta$-catenin, which clearly delineate the membranes of SEZ cells, indicated that subependymal cells did not appear to contain detectable levels of $\alpha$-SYN (Fig. 2b). In contrast, high levels were found in synaptophysin ${ }^{+}$and $\mathrm{TH}^{+}$fibers supplying the adjacent striatum, some of which entered the SEZ and were in close proximity to many $\mathrm{GFAP}^{+}$/ Sox $2^{+}$cells ( $46 \pm 2 \%, n=3$; Fig. $2 b-e$ ). Whole-mount en face preparations of the lateral ventricle wall unmasks a cytoarchitectural organization in repetitive units, named pinwheels, composed of rosettes of ependymal cells surrounding very slender cytoplasmic processes of B1 cells that end in a primary cilium in contact with the ventricular CSF (Mirzadeh et al., 2008). Confocal 3D reconstructions of SEZ whole mounts revealed $\alpha-\mathrm{SYN}^{+}$ puncta in close apposition to $\mathrm{GFAP}^{+} \mathrm{B1}$ cell processes traced from the ventricular surface (Fig. 2f), suggesting the possibility that $\alpha$-SYN could be a niche regulator of NSCs. In agreement with this possibility, we scored reduced densities of pinwheels and of $\mathrm{GFAP}^{+}$uniciliated $\mathrm{B} 1$ cells in whole mounts of 2 month Snca mutants (Fig. 3a,b). Likewise, we found reduced proportions of $\mathrm{GFAP}^{+}$cells (Fig. $3 c, d$ ) or $\mathrm{GFAP}^{+} / \mathrm{Sox} 2^{+}$cells $(12.5 \pm 1.7 \%$ in $\mathrm{Snca}^{+/+}$vs $3.9 \pm 0.7 \%$ in Snca $^{-/-}$mice, $n=3, p<0.01$; Fig. $3 c, d)$ and reduced proportions of $\mathrm{GFAP}^{+}$cells, which were also positive for the proliferation marker Ki67 (Fig. 3c,d). The proportion of Ascl1 ${ }^{+}$ cells at 2 months was, however, similar be-

\section{$\leftarrow$}

the response to 0 sticks. Snca ${ }^{+/+}$mice reacted to geraniol sticks 1-3 and then habituated during subsequent $4-6$ exposures, and reacted again to the first presentations of $($ sticks. Snca ${ }^{-1-}$ mice, however, displayed lower olfactory exploration and no reaction to the second stimulus. At 12 months, the two genotypes showed age-related olfactory deficits but no differences between them. $\boldsymbol{f}$, Representative immunofluorescent detection of $\mathrm{BrdU}^{+}$(red) in $\mathrm{OB}$ coronal sections of $\mathrm{SnCa}^{+/+}$and Snca ${ }^{-/-}$mice. White arrowheads point at $\mathrm{BrdU}^{+}$cells. Data are mean \pm SEM of a number of independent mice indicated in parentheses. ${ }^{*} p<0.05$ (Student's $t$ test). ${ }^{* *} p<0.01$ (Student's t test). Scale bar: $\boldsymbol{f}, 20 \mu \mathrm{m}$. 

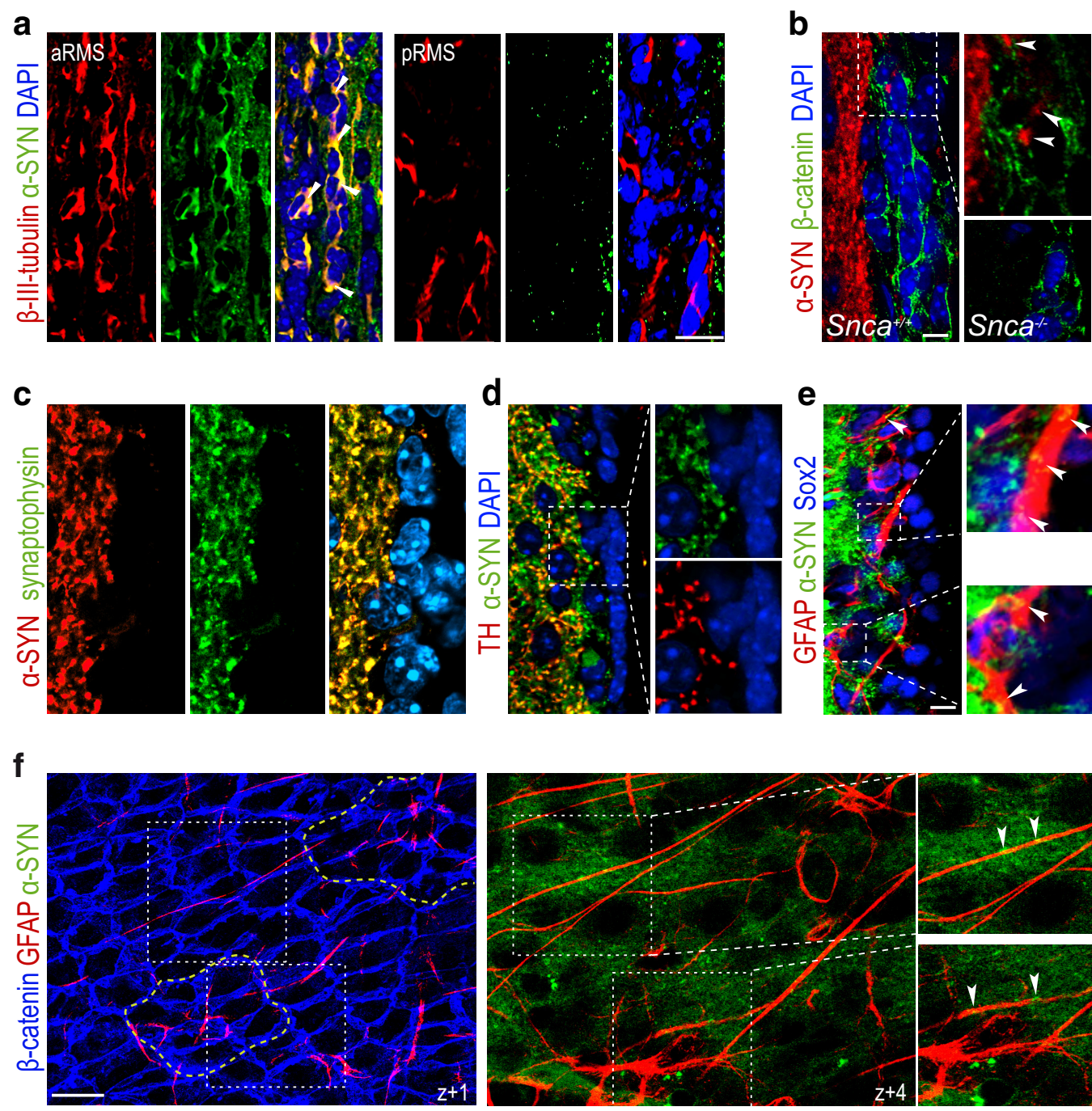

Figure 2. $\quad \alpha$-SYN is present in fibers supplying the SEZ. $a$, Immunofluorescent detection of $\alpha$-SYN (green) and $\beta$-III-tubulin (red) in coronal sections through the anterior (a) and posterior (p) half of the RMS. White arrowheads point at doubly positive cells present only in the aRMS. DAPI was used as a counterstain. $\boldsymbol{b}$, Immunofluorescent detection of $\alpha$-SYN (red) and $\beta$-catenin (green) to label cell membranes in the SEZ in Snca ${ }^{+/+}$and Snca ${ }^{-/-}$mice as a specificity control. White arrowheads point at puncta within the SEZ region. c, Synaptic distribution of $\alpha$-SYN (red) observed by colocalization with synaptophysin ${ }^{+}$(green). $\boldsymbol{d}$, Synaptic colocalization of $\alpha$-SYN (green) with TH ${ }^{+}$(red). There is characteristic punctate staining of nerve terminals and the lack of staining in SEZ cells in the high-power micrographs (right) of the area indicated by the square. $e$, Low-power confocal micrographs showing the immunofluorescent detection of $\alpha$-SYN (green), GFAP (red), and Sox2 (blue) and high-power images of the areas indicated by the white squares. $\alpha$-SYN ${ }^{+}$terminals are closely adjacent to $\mathrm{GFAP}^{+}$Sox2 ${ }^{+}$cells (indicated by white arrowheads).f, Serial confocal sections through a SEZ whole mount at different $z$ levels from the ventricular surface $(z+0)$ show the staining for $\beta$-catenin (blue), GFAP (red), and $\alpha$-SYN (green). Dotted yellow lines indicate two pinwheels. Different GFAP ${ }^{+} \mathrm{B} 1$ cells traced in the $z$-axis from the ventricular surface with $\alpha$-SYN ${ }^{+}$puncta closely apposed (white arrowheads) as shown at a higher magnification of the dotted white lined square. DAPI (blue) was used for nuclear staining. Scale bars: $\boldsymbol{a}, 20 \mu \mathrm{m} ; \boldsymbol{b}-\boldsymbol{f}, 10 \mu \mathrm{m}$.

tween genotypes (relative to DAPI: $14.8 \pm 0.8 \%$ in $\mathrm{Snca}^{+/+}$vs $17.4 \pm 0.7 \%$ in $\mathrm{Snca}^{-1-}$ mice, $\left.n=4\right)$, indicating that progression into TAP cells was not affected by the mutation. The SEZ matures to its final cytoarchitectural organization and becomes innervated during the first 2 weeks after birth (Tramontin et al., 2003; Bjornsson et al., 2015). Analyses at postnatal day 7 revealed normal proportions of $\mathrm{GFAP}^{+}$cells $\left(13.2 \pm 2.8 \%\right.$ in $\mathrm{Snca}^{+/+}$vs $14.0 \pm 3.1 \%$ in Snca ${ }^{-1-}$ mice, $\left.n=3\right)$ and of $\mathrm{GFAP}^{+}$cells that were positive for Ki67 $\left(43.4 \pm 3.0 \%\right.$ in Snca $^{+/+}$vs $45.1 \pm 12.7 \%$ in Snca ${ }^{-1-}$ mice, $n=3$; Fig. 3e), suggesting that $\alpha$-SYN is required for the maintenance and activity, but not the generation, of adult subependymal NSCs.

We next asked ourselves about the specific effects of $\alpha$-SYN in NSC biology. We observed reduced proportions of $\mathrm{GFAP}^{+}$cells with detectable levels of the activation marker EGFR (23.0 \pm $2.0 \%$ in $\mathrm{Snca}^{+/+}$vs $14.8 \pm 2.0 \%$ in Snca ${ }^{-/-}$mice, $n=3, p<$
$0.05)$ accompanied by increased proportions of $\mathrm{GFAP}^{+}$cells that were also positive for $\mathrm{S} 100 \beta$ (Fig. $3 d$ ), a calcium-binding protein, which is a marker of non-neurogenic mature astrocytes (Raponi et al., 2007; Codega et al., 2014), suggesting that activated NSCs were becoming prematurely exhausted in the absence of $\alpha$-SYN. Activated (a)NSCs coexist in the SEZ with dormant or quiescent (q)NSCs, and these two populations can be detected by flow cytometry using specific marker combinations (Codega et al., 2014; Mich et al., 2014; Llorens-Bobadilla et al., 2015; Chaker et al., 2016); therefore, we decided to quantitatively analyze the fraction of quiescent and activated NSCs using this methodology in SEZ dissociates of 2.5 month mice. Elimination of $\mathrm{CD} 45^{+} / \mathrm{CD} 31^{+} /$ Ter $119^{+} / \mathrm{O}^{+}\left(\right.$lin $\left.^{+}\right)$cells (microglia and circulating lymphocytes, endothelial cells, erythrocytes, and oligodendrocytes) was followed by cell labeling using antibodies to the glial marker GLAST, the cell progeny marker CD24, the tetraspanning CD9, 

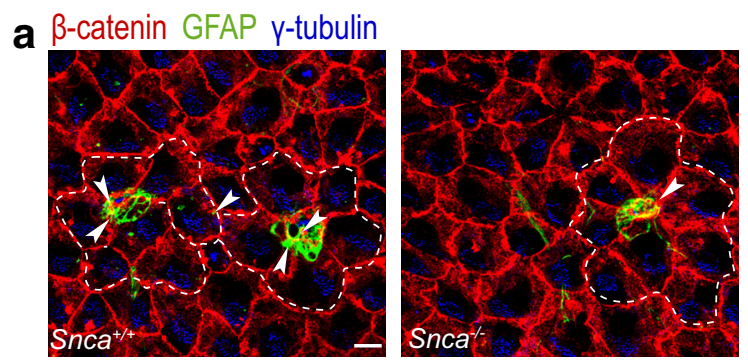

C
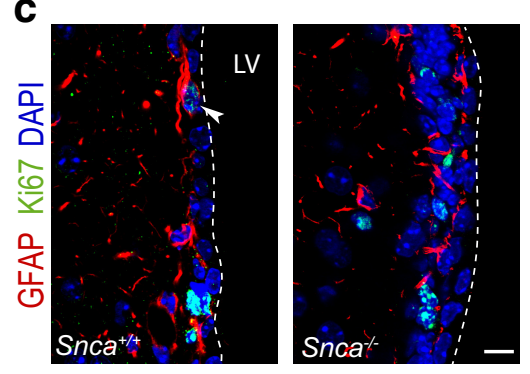

2-m

f

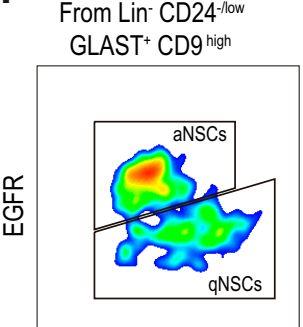

GLAST

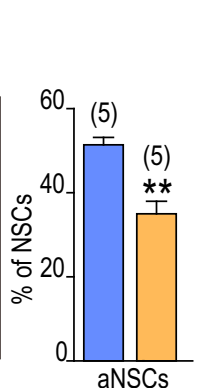

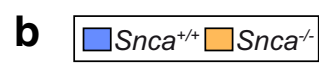

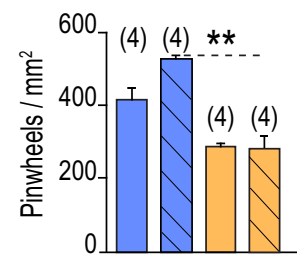

d

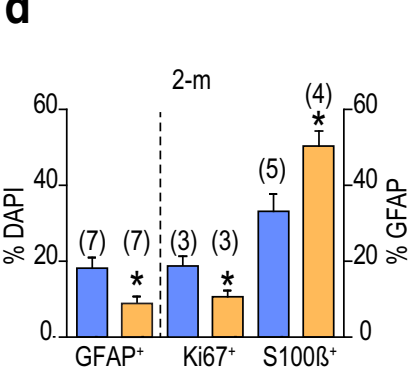

g

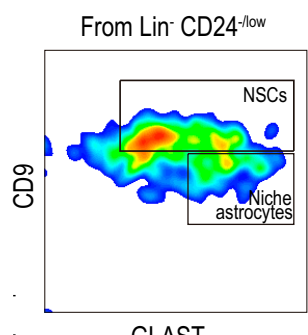

GLAST e
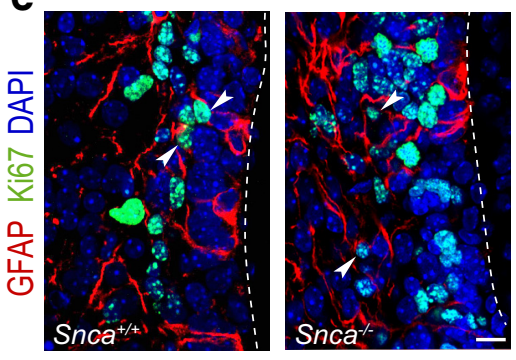

postnatal day 7
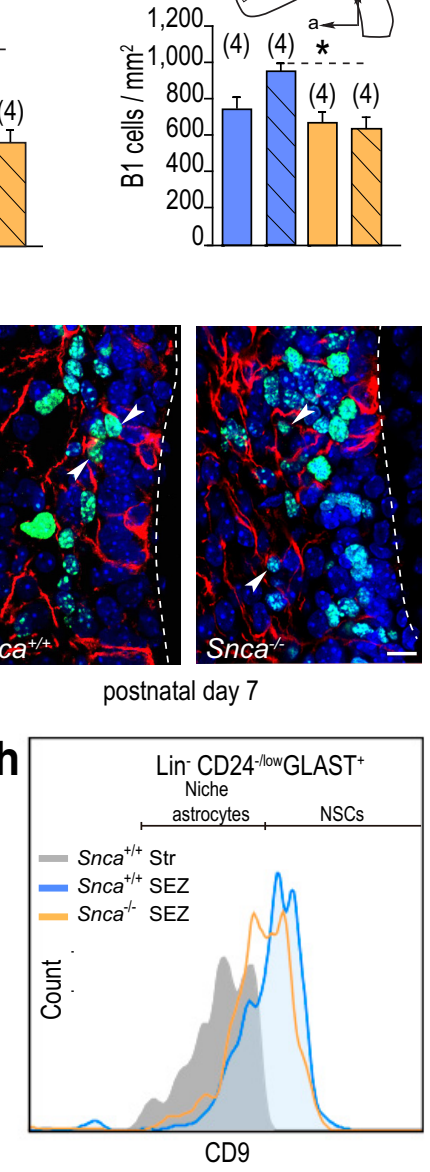

Figure 3. $\alpha$-SYN is required for the maintenance, but not the generation, of adult subependymal NSCs. $a$, Representative SEZ whole-mount preparations of 2 month mice immunostained for $\gamma$-tubulin (blue), $\beta$-catenin (red), and GFAP (green). White dashed lines indicate examples of pinwheels. $\boldsymbol{b}$, Pinwheel and B1 cell density per mm ${ }^{2}$ at the anterodorsal (plain) and posterodorsal (striped) SEZ regions. Snca knock-out mice display lower density of pinwheels and B1 cells than wild-type littermates. c, Representative immunofluorescent detection of GFAP (red) and Ki67 (green)

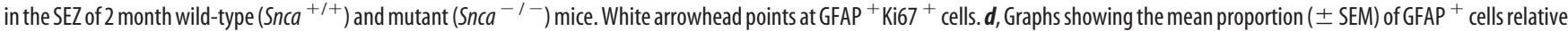
to total number of cells (on the left axis) and GFAP ${ }^{+}$cells that are in cell cycle (Ki67 ${ }^{+}$) or express S100 $\beta$ in the SEZ of Snca ${ }^{+/+}$and Snca ${ }^{-\prime-}$ mice at 2 months (on the right axis). e, Representative immunofluorescent detection of GFAP (red) and Ki67 (green) in the SEZ of postnatal day 7 mice. White arrowheads point at GFAP ${ }^{+}$Ki67 ${ }^{+}$cells. DAPI was used for nuclear staining. $f$, FACS analysis of qNSCs and aNSCs within the Lin ${ }^{-} / \mathrm{CD}_{24}{ }^{-/ \text {low }} / \mathrm{GLAST}^{+} / \mathrm{CD}^{\text {high }}$ population discriminated by EGFR expression, showing a decrease in aNSCs in mutant mice. $\boldsymbol{g}$, FACS analysis for CD9 in the $\mathrm{Lin}^{-} / \mathrm{CD} 24^{- \text {/low }} / \mathrm{GLAST}^{+}$population showing an apparent increase in niche CD9 ${ }^{\text {low }}$ astrocytes in mutant mice. $\boldsymbol{h}$, Graph representing the levels of CD9 expression in SEZ NSCs and in striatal astrocytes of wild-type mice and in cells of the mutant SEZ (orange line). ${ }^{*} p<0.05$ (Student's t test). ${ }^{* *} p<0.01$ (Student's t test). ${ }^{* *} p<0.001$ (Student's t test). Scale bars: $\boldsymbol{a}, \boldsymbol{c}, \boldsymbol{e}, 10 \mu \mathrm{m}$.

which is more highly expressed in NSCs than in astrocytes, and a fluorescently labeled EGF to label the EGFR, which is absent in qNSCs (Codega et al., 2014; Mich et al., 2014; Llorens-Bobadilla et al., 2015). The population of NSCs was defined as those cells that were $\mathrm{GLAST}^{+} / \mathrm{CD} 24^{-/ \mathrm{lo}} / \mathrm{CD} 9^{\text {high }}$ and represented $2.2 \pm 0.2 \%$ $(n=5)$ of all cells in the SEZ homogenate; among them, aNSCs or NSCs with detectable levels of EGFR represented $\sim 45 \%-$ $50 \%$ of all NSCs. In line with our histological analysis, Snca mutants had reduced proportions of aNSCs (Fig. $3 f$ ). Interestingly, we also found a reduction in the proportion of CD9 $9^{\text {high }}$ cells among the GLAST ${ }^{+}$population as some of these cells exhibited CD9 levels more similar to those of striatal astrocytes (Fig. $3 g, h)$. This, together with the increase in $\mathrm{GFAP}^{+}$cells that were also $\mathrm{S} 100 \beta^{+}$, correlated with the loss of neurogenic potential in the Snca mutants.

A fraction of B cells of the SEZ can incorporate and retain BrdU for several weeks due to their long cell cycles (Maslov et al., 2004; Codega et al., 2014). To test whether $\alpha$-SYN was indeed acting directly on these activated B cells, we injected 2.5 month mice with BrdU and allowed the animals to survive a month. We found reduced numbers of label-retaining cells (BrdU-LRCs) in the SEZ of Snca mutant versus wild-type mice (508 \pm 36 in Snca ${ }^{+/+}, n=4$, and $338 \pm 23$ in Snca ${ }^{-/-}$mice, $\left.n=6, p<0.01\right)$; but, more importantly, the proportion of BrdU-LRCs, which were $\mathrm{S} 100 \beta^{+}$, was significantly increased in null mice (14.0 \pm $2.1 \%$ in $\mathrm{Snca}^{+/+}, n=11$ vs $28.7 \pm 4.0 \%$ in $\mathrm{Snca}^{-/-}$mice, $n=9$, $p<0.01$ ), suggesting that aNSCs were indeed withdrawing from the cell cycle and engaging terminal differentiation. Interestingly, the total number of BrdU-LRCs $\left(351 \pm 102\right.$ in $\mathrm{Snca}^{+/+}, n=6 \mathrm{vs}$ $375 \pm 28$ in $\mathrm{Snca}^{-/-}$mice, $\left.n=4\right)$ and the frequency of BrdULRCs that were terminally differentiated into $S 100 \beta^{+}$astrocytes $\left(42.3 \pm 3.9 \%\right.$ in $\mathrm{Snca}^{+/+}$vs $49.3 \pm 3.3 \%$ in $\mathrm{Snca}^{-/-}$mice, $\left.n=3\right)$ did not differ and were equally lower in the two genotypes at 12 months. All these data together with the olfactory behavior suggested that $\alpha$-SYN is necessary to maintain activated B1 cells undifferentiated, preventing or delaying a premature terminal differentiation into mature resident astrocytes. 


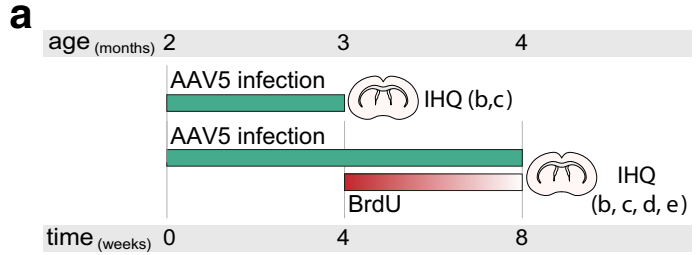

b h-a-SYN

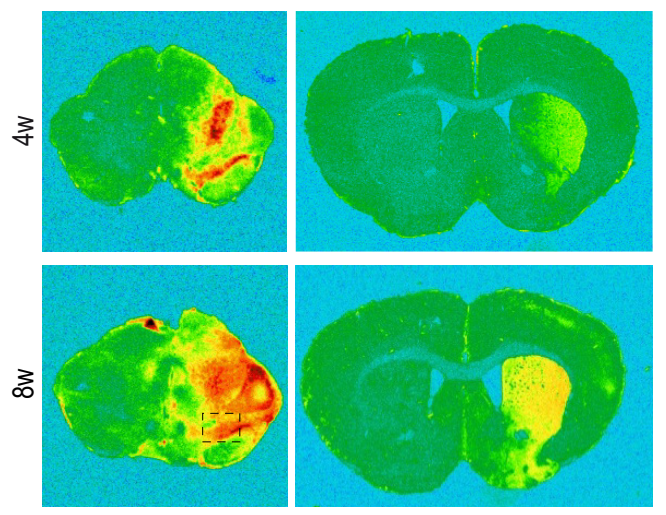

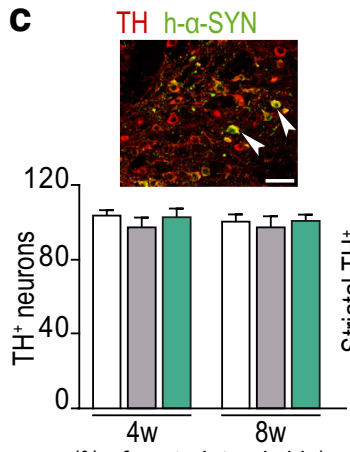

( $\%$ of contralateral side)

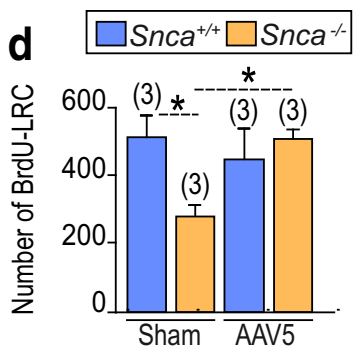

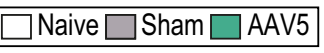

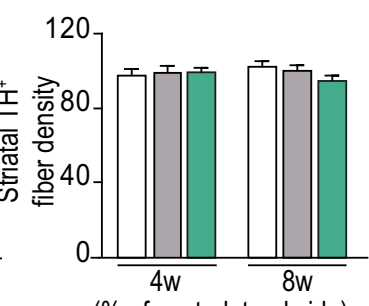

( $\%$ of contralateral side)

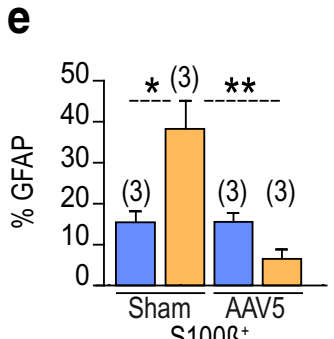

Figure 4. $\quad \alpha$-SYN present in DAergic nigral synaptic terminals prevents differentiation of NSCs into non-neurogenic astrocytes. $a$, Experimental protocol for AAV5-CBA-h- $\alpha$-Syn SNpc infection and subsequent analysis. $\boldsymbol{b}$, Detection of human $\alpha$-SYN expression in the hemispheres ipsilateral and contralateral to the infection at the levels of the mesencephalon and striatum 4 and 8 weeks after the surgery. $c$, Representative immunofluorescent detection of TH (red) and $\alpha$-SYN (green) in the SNpc ipsilateral to the viral injection. Quantification of the number of TH ${ }^{+}$neurons and the density of $\mathrm{TH}^{+}$fibers in the striatum in naive, sham, and AAV5-CBA-h- $\alpha$-SYN mice, evaluated 4 and 8 weeks after the adenovirus injection. $\boldsymbol{d}$, Quantification of BrdU-LRCs in the SEZ of sham-operated and virus-infected Snca ${ }^{+/+}$and Snca ${ }^{-/-}$mice. $e_{\text {, Histogram showing the proportions of GFAP }}^{+}$subependymal cells that are also S100 $\beta^{+}$in sham or infected Snca ${ }^{+/+}$and Snca ${ }^{-1-}$ mice 8 weeks after the surgery. ${ }^{*} p<0.05$ (two-way ANOVA). ${ }^{* *} p<0.01$ (two-way ANOVA). Scale bar: $c, 20 \mu \mathrm{m}$.

Among $\alpha$-SYN ${ }^{+}$terminals supplying the SEZ, many also contain detectable levels of TH (Fig. $2 b$ ) and originate in the ventral mesencephalon (Freundlieb et al., 2006; Lennington et al., 2011; Höglinger et al., 2014). To evaluate the possibility that lack of $\alpha$-SYN in DAergic fibers was responsible for the neurogenic phenotype of the Snca mutant mice, we stereotactically injected AAV 5 carrying a $\beta$-actin promoter-driven human $\alpha$-SYN cDNA (AAV5-CBA-h- $\alpha$-Syn) into the SNpc of 2 month Snca wild-type and mutant mice (Fig. 4a). This procedure results in the expression of $\alpha$-SYN in nigral neurons without causing neurodegeneration or decrease in $\mathrm{TH}^{+}$fibers (Fig. 4b,c). Unilaterally infected or sham-operated mice were injected with BrdU 4 weeks after the surgery and allowed to survive for 4 more weeks. In contrast to the sham situation, the number of BrdU-LRCs did not differ between infected Snca wild-type and mutant mice in the SEZ ipsilateral to the injection (Fig. 4d), indicating that restoration of $\alpha$-SYN levels maintains B1 cells in a cycling state allowing them to incorporate BrdU. Moreover, restoration of $\alpha$-SYN in the knock-outs reduced the proportion of $\mathrm{GFAP}^{+}$cells that were also $S 100 \beta^{+}$to wild-type levels 8 weeks after the infection (Fig. 4e). These data indicated that $\alpha$-SYN present in DAergic nigral synaptic terminals prevents exit from cell cycle and differentiation of NSCs into non-neurogenic astrocytes. Furthermore, the results reinforce the idea that $\alpha$-SYN is required in the adult mature SEZ, in line with a lack of phenotype in early postnatal mutant animals.

\section{Subependymal neurogenic potential is sustained by a functional nigrostriatal pathway}

Because Snca-null mice exhibit reportedly reduced levels of total striatal DA (Abeliovich et al., 2000), we considered the possibility that DA availability could be playing a role in NSC maintenance.
Interestingly, striatal DA levels become significantly reduced at 12 and 24 months compared with the levels measured at 2 months by HPLC (Fig. 5a). We therefore decided to evaluate whether sustained levels of DA are indeed required for the maintenance of B1 cells by subcutaneously injecting 3 month mice with MPTP, which selectively lesions DAergic neurons (Fig. 5b). Most MPTP treatments in vivo aimed at evaluating effects of DA loss in neurogenesis have been acute or subacute, meaning that a dose of MPTP ranging from 20 to $50 \mathrm{mg} / \mathrm{kg}$ of body weight was repeatedly injected during a $48 \mathrm{~h}$ interval, and mice were killed between 2 and $21 \mathrm{~d}$ later (Höglinger et al., 2004; Yamada et al., 2004). Instead, we used a chronic regimen, consisting of three injections of $20 \mathrm{mg} / \mathrm{kg}$ MPTP per week during 3 months, to better reproduce the progressive nature of PD (Muñoz-Manchado et al., 2013). The striatum and SEZ of MPTP-treated mice were largely devoid of $\mathrm{TH}^{+}$fibers (Fig. 5c), and we could observe a reduction in the proportion of Ki67 ${ }^{+}$-activated $\mathrm{GFAP}^{+}(15.5 \pm$ $1.5 \%$ in saline-injected, $n=7$ vs $10.2 \pm 1.0 \%$ in MPTP-injected mice, $n=6, p<0.05)$ or $\mathrm{GFAP}^{+}$Sox $2^{+}(25.3 \pm 1.8 \%$ in salineinjected vs $17.0 \pm 1.3 \%$ in MPTP-injected mice, $n=3, p<0.05$ ) cells at the end of the treatment. Similarly to the Snca mutant phenotype, reduced proportions of proliferating $\mathrm{GFAP}^{+}$cells were accompanied by an elevated incidence of $\mathrm{GFAP}^{+} S 100 \beta^{+}$ cells in MPTP-treated wild-type mice (Fig. $5 d$ ). Because the results suggested that DAergic fibers contribute to B1 cell cycling, we treated another group of mice with the same MPTP regimen, injected them with BrdU in the last day of the treatment, and allowed them to survive for 4 more weeks. We found reduced numbers of BrdU-LRCs in DA-depleted animals (Fig. 5e), indicating that synaptic DA regulates the cycling of activated NSCs in addition to its previously reported effects on TAP cell proliferation (Höglinger et al., 2004; O'Keeffe et al., 2009). 
a
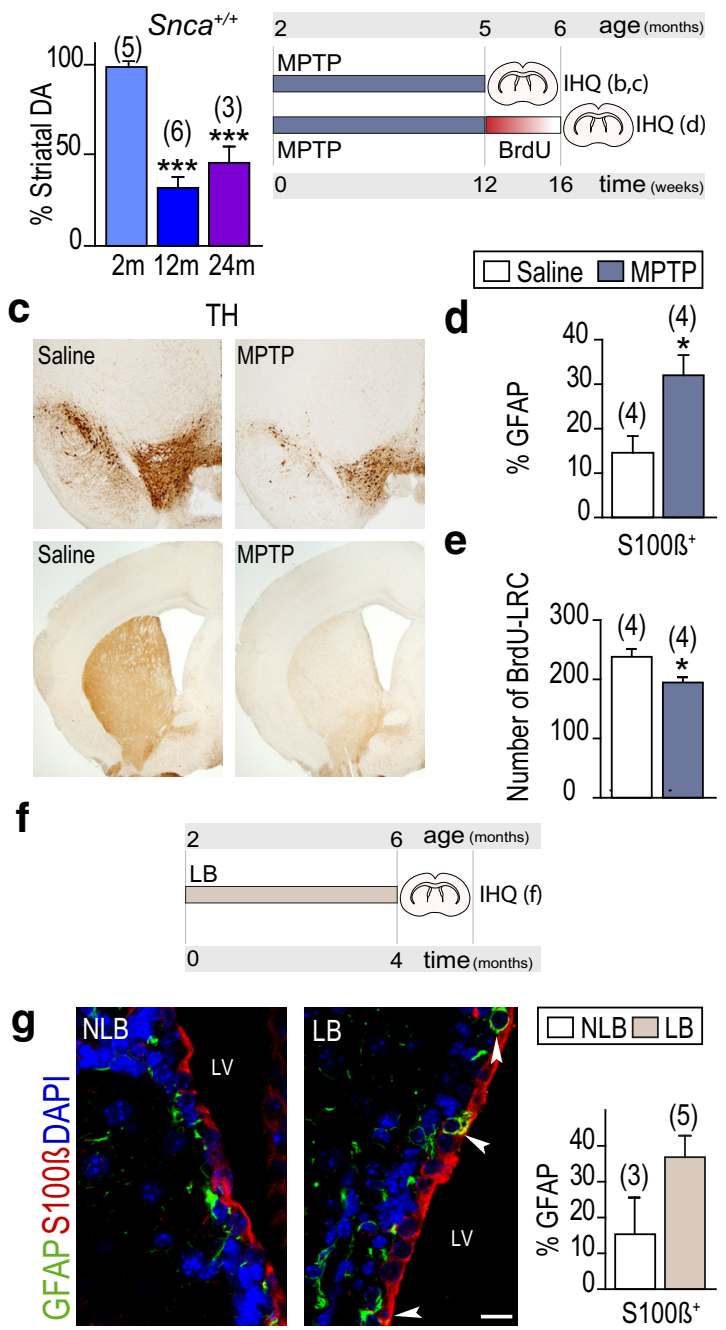

Figure 5. Dopamine maintains NSCs in an undifferentiated cycling state. $\boldsymbol{a}$, Striatal content of dopamine in wild-type mice at 2, 12, and 24 months (m). $\boldsymbol{b}$, MPTP experimental design. c, Immunoperoxidase detection of TH in coronal sections of SNpc (top) and the striatum (bottom) of mice chronically treated with saline or MPTP. $\boldsymbol{d}$, Proportion of $S 100 \beta^{+}$among GFAP ${ }^{+}$cells. e, Number of subependymal BrdU LRCs. $\boldsymbol{f}$, Experimental design of the intranigral inoculation of LB and non-LB fractions. $\boldsymbol{g}$, Immunofluorescent detection of $S 100 \beta$ (red) and GFAP (green) in mice inoculated with NLB or LB fractions 4 months before death. White arrowheads point at double-positive cells. LV, Lateral ventricle. Proportion of $S 100 \beta^{+}$among GFAP ${ }^{+}$cells. ${ }^{*} p<0.05$ (Student's t test). ${ }^{* *} p<$ 0.0001 (one-way ANOVA). Scale bar: $\boldsymbol{g}, 10 \mu \mathrm{m}$.

In another set of experiments, nigral LB-enriched fractions of pathological $\alpha$-SYN purified by sucrose gradient from postmortem PD brains, or fractions lacking toxic $\alpha-S Y N$ as controls (non-LB), were stereotactically inoculated into the SNpc of 2 month mice that were evaluated 4 months after the surgery. We had previously shown that pathological $\alpha$-SYN initiates a slowly progressive axon-initiated DAergic nigrostriatal degeneration (Recasens et al., 2014). Loss of striatal and, hence, subependymal $\mathrm{TH}^{+}$fibers was again accompanied by an increase in the proportion of $\mathrm{GFAP}^{+}$cells which were also positive for the astrocyte marker $\mathrm{S} 100 \beta$ (Fig. $5 f, g$ ). The results found in chronic models of experimental parkinsonism together indicated that DA is required to maintain $\mathrm{GFAP}^{+} \mathrm{B1}$ cells undifferentiated. a

b
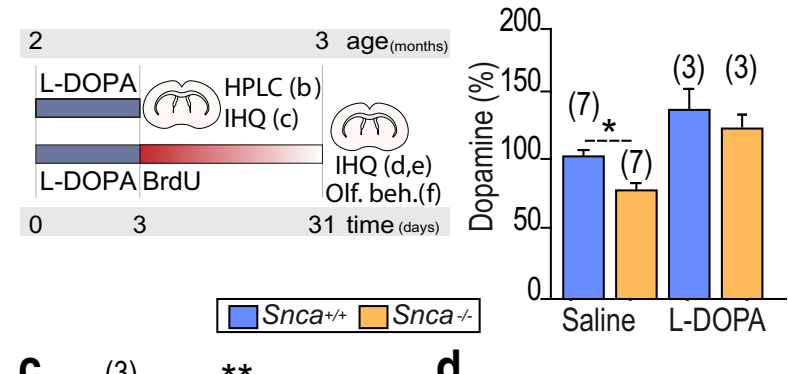

c
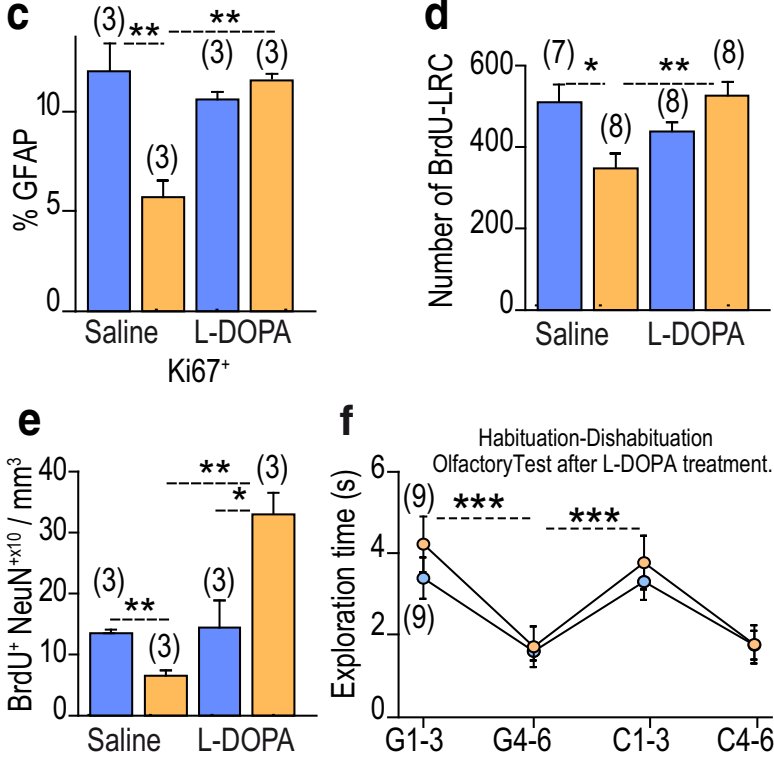

Figure 6. Restoration of the aged-like neurogenic phenotype of Snca mutants by L-DOPA. $\boldsymbol{a}$, L-DOPA experimental design. $\boldsymbol{b}$, Striatal content of dopamine in Snca ${ }^{+/+}$and Snca ${ }^{-1-}$ mice treated with saline or L-DOPA relative to the control situation. c, Proportion of Ki67 ${ }^{+}$ among GFAP $^{+}$cells in Snca ${ }^{+/+}$and Snca ${ }^{-/-}$mice treated with saline or L-DOPA.d, Number of subependymal BrdU-LRCs in Snca ${ }^{+/+}$and Snca ${ }^{-/-}$mice treated with saline or L-DOPA. $\boldsymbol{e}$, Density of BrdU ${ }^{+} \mathrm{NeuN}^{+}$newly generated neurons in the OB glomerular layer in Snca ${ }^{+/+}$ and Snca ${ }^{-1-}$ mice treated with saline or L-DOPA. $f$, Olfactory habituation-dishabituation test in Snca ${ }^{+/+}$and Snca ${ }^{-/-}$mice treated with L-DOPA. ${ }^{*} p<0.05$ (two-way ANOVA). ${ }^{* *} p<$ 0.01 (two-way ANOVA). ${ }^{* * *} p<0.001$ (two-way ANOVA).

Neurogenic deficits of young, but not old, Snca-null mice can be restored by DAergic pharmacotherapy

Based on the above observations, we next set out to study whether reduced DA levels and/or availability could underlie the defects in B1 cell behavior in the absence of $\alpha$-SYN, by exogenously raising DA levels. To do so, we injected 2 month Snca wild-type and mutant mice with one intraperitoneal injection of $5 \mathrm{mg} / \mathrm{kg}$ benserazide, to block peripheral decarboxylation, followed 30 min later by another injection of either $20 \mathrm{mg} / \mathrm{kg} \mathrm{L}$-DOPA in saline plus 0.5 $\mathrm{mg} / \mathrm{ml}$ ascorbic acid or vehicle solution alone for 3 consecutive days, and killed the animals $24 \mathrm{~h}$ after the last injection (Fig. 6a). HPLC analyses indicated that systemic administration of L-DOPA resulted in elevated levels of striatal DA and eliminated differences between genotypes (Fig. 6b). Furthermore, the rise in the level of DA did not result in the activation of $\mathrm{GFAP}^{+}$cells in wild-type mice but restored the proportions of $\mathrm{GFAP}^{+}$cells that were $\mathrm{Ki} 67^{+}$in mutants to wildtype levels (Fig. $6 c$ ). In another set of mice injected with BrdU on the last day of the L-DOPA treatment and allowed to survive for 4 weeks, we found that the numbers of BrdU-LRCs in the SEZ as well as the density of $\mathrm{BrdU}^{+} \mathrm{NeuN}^{+}$new periglomerular neurons had been also restored by DA pharmacotherapy (Fig. $6 d, e$ ). These data to- 
gether indicated that DA contributes to the maintenance of the undifferentiated, and therefore cycling, neurogenic status of NSCs and suggested that $\alpha$-SYN may be required to mediate DA availability to NSCs. In line with increased proliferation in the SEZ and neurogenesis to the OB, the olfactory deficits of Snca mutants were also restored by the treatment with L-DOPA (Fig. $6 f$ ).

Our results suggested that a certain level of DA is necessary to maintaining NSCs in their cycling state and that L-DOPA contributed to this maintenance in animals with lower levels of DA. To further test this possibility, we decided to evaluate whether increased levels of DA would restore cycling in elderly mice that exhibit reduced levels of neurogenesis due to decreased numbers of activated NSCs that are less likely to undergo cellular division (Maslov et al., 2004; Luo et al., 2006). As shown above, 12 month mice of both genotypes exhibited reduced percentages of BrdULRCs in the SEZ compared with 2 month mice. These numbers did not change when the animals were injected with L-DOPA (saline-injected: $1.3 \pm 0.2$ in $\mathrm{Snca}^{+/+}$and $1.1 \pm 0.3$ in $\mathrm{Snca}^{-/-}$ mice; L-DOPA-injected: $1.1 \pm 0.4$ in $\mathrm{Snca}^{+/+}$and $1.1 \pm 0.2 \mathrm{in}$ $\mathrm{Snca}^{-/-}$mice, $\left.n=3\right)$. Likewise, the proportion of periglomerular $\mathrm{BrdU}^{+}$neurons, which was always lower than in young mice, was not modified by the treatment in any of the genotypes and remained unchanged (saline-injected: $4.0 \pm 0.8 \mathrm{BrdU}^{+}$cells $\times$ $10 / \mathrm{mm}^{3}$ in $\mathrm{Snca}^{+/+}$and $3.9 \pm 0.7$ in $\mathrm{Snca}^{-/-}$mice; L-DOPAinjected: $3.9 \pm 0.3$ in $\mathrm{Snca}^{+/+}$and $2.8 \pm 0.9 \mathrm{in} \mathrm{Snca}^{-/-}$mice, $n=3)$. These data suggested that DA acts on cells that can still proliferate preventing their differentiation but cannot revert their terminally differentiated state.

\section{Discussion}

We have identified an essential requirement for DA and DAergic synaptic $\alpha$-SYN in adult NSC maintenance. Our data add to previously reported effects of DA on TAP cell proliferation and suggest the possibility that niche regulation by DA could contribute also to the long-term maintenance of neurogenic potential. Moreover, our results uncover a novel role of $\alpha$-SYN in NSC maintenance, likely through the regulation of DA availability. Our data indicate a previously unexplored relationship between $\alpha$-SYN dysfunction and premature neurogenic senescence and support a model whereby $\alpha$-SYN is necessary for the effects of DA extrasynaptic neurotransmission in the maintenance of neurogenic potential in the SEZ.

In the dentate gyrus, normal $\alpha$-SYN appears necessary for the survival and differentiation of newly generated neurons (Winner et al., 2012), whereas a detrimental effect is synergistically played by DA depletion and post-translational modifications of $\alpha$-SYN (Schlachetzki et al., 2016). As with regards to gain-of-function experiments, decreased numbers of newly generated neurons have been observed in the $\mathrm{OB}$ of transgenic mice overexpressing wild-type or mutated human $\alpha$-SYN (Winner et al., 2004, 2008; Nuber et al., 2008; Marxreiter et al., 2009, 2013; Peng and Andersen, 2011; Winner and Winkler, 2015). However, the promoters used to drive the expression of $\alpha$-SYN in these studies are activated only in neurons and, indeed, in many of these instances, reduced olfactory neurogenesis and neuroblast survival occurred in the absence of consistent changes in progenitor proliferation. Uncovering which phenotypes are the result of a complete $\alpha$-SYN elimination, such as those described here, can help define the involvement of the protein in normal physiology. But they could potentially also help in the elucidation of the pathogenic role of this molecule. Misfolded $\alpha$-SYN accumulates in LB of PD-affected nigral neurons likely resulting in its loss in nerve terminals; therefore,
Snca mutants may be recapitulating some of the pathological features of PD.

The contribution of neurogenesis to the pathology of neurodegenerative disorders is currently an area of intense investigation. PD motor cardinal symptoms are frequently accompanied by a broad spectrum of nonmotor dysfunctions, including anxiety, depression, and alterations in olfactory perception or mood (Obeso et al., 2014). This together with reports of reduced proliferation in germinal areas of postmortem PD brain samples had suggested that adult neurogenesis could also be affected by the disease (Winner and Winkler, 2015). However, two main issues account for the difficulty in relating potential alterations in olfactory neurogenesis to PD (Huisman et al., 2004; Marxreiter et al., 2013). First, recent evidence indicates that OB neurogenesis in humans is restricted to very early postnatal ages (see, e.g., Ernst et al., 2014). Second, DA actions on progenitor populations of the adult brain are not completely understood, as different studies have provided some inconsistent results. It has been reported that postmortem brains of PD patients display reduced numbers of cells that are positive for the cell cycle marker PCNA in the subependymal and subgranular zones (Höglinger et al., 2004). In rodents, most studies indicate that DAergic innervation to the SEZ positively regulates the cycling activity of EGFR ${ }^{+}$TAP cells, although suppression of DA signaling or chronic treatments with DA antagonists have raised the alternative possibility that DA is a negative regulator of progenitor proliferation (Baker et al., 1993; Coronas et al., 2004; Höglinger et al., 2004; Van Kampen et al., 2004; Yamada et al., 2004; Freundlieb et al., 2006; Winner et al., 2006, 2009; O'Keeffe et al., 2009; Kim et al., 2010; Lao et al., 2013). The situation is far less understood as with regards to B1 cells. A previous report suggested that DA inhibits the proliferation of B1 cells, but the data were derived from very long treatments with a D2R antagonist (Kippin et al., 2005). Moreover, an increase in BrdU incorporation by GFAP ${ }^{+}$cells of the SEZ or no change at all following D3R activation with two different agonists have been reported (Kim et al., 2010; Lao et al., 2013). These apparently contradictory results may reflect compensatory changes to different DAergic situations or the complexity of DA actions in terms of signaling or receptive cells (Liu et al., 2006; Aponso et al., 2008; Park and Enikolopov, 2010).

We propose here that DA is required to maintain the cycling status of B1 cells. Moreover, because exogenous DA administration does not affect neurogenesis in wild-type mice, we propose that a certain threshold level of DA is required to prevent cell cycle exit and/or terminal differentiation and that compromised DA availability, as in cases of $\alpha$-SYN dysfunction or aging, can result in loss of NSC potential. This effect has important consequences as cells abandon the stem cell compartment leading to permanent changes. The effects of DA (and of $\alpha$-SYN-regulated DA availability) in NSCs could be mediated by actions on EGFR. Although EGFR has been considered for quite some time a marker of TAP cells, it is present and regulates aNSCs; it has been reported that the levels of EGFR in the SEZ in vivo are reduced in animals treated with 6-OHDA and treatment of neurospheres with DA induces the release of EGF, a secretion that requires activation of the EGFR (O'Keeffe et al., 2009). The levels of EGFR are significantly reduced as mice age (Enwere et al., 2004), and we have found that the proliferation of NSCs in 12 month mice cannot be restored by increasing DA levels. Moreover, EGF reportedly prevents the maturation of $\mathrm{GFAP}^{+}$SEZ cells toward nonmultipotent $\mathrm{S} 100 \beta^{+}$astrocytes (Raponi et al., 2007). Therefore, reduced DA levels could play a role both in PD brains and during aging. 
Slight changes in $\alpha$-SYN synaptic levels appear to have significant effects on neurotransmitter release (Al-Wandi et al., 2010), and $\alpha$-SYN is considered a synaptic modulator, although its specific function is not fully understood yet. Young mice lacking synucleins exhibit increases in SNARE, complexin, and synapsin proteins, and $\alpha$-SYN promotes survival through cooperation with the presynaptic chaperone $\operatorname{CSP} \alpha$, possibly at a step regulated by SNAREs (Lou et al., 2017). Work with multiple mutants of synucleins suggests that $\alpha$-SYN is the most efficient family member in maintaining normal levels of DA throughout adulthood, whereas $\beta$-SYN may compensate for $\alpha$-SYN loss in young, but not in aged, animals (Connor-Robson et al., 2016). Under demanding conditions requiring fine tuning of functional capabilities, loss of function or incomplete compensation from other members of the synuclein family can be especially detrimental in aged individuals or when $\alpha$-SYN aggregates, as it occurs in $\alpha$-synucleinopathies. Once released, DA can diffuse a certain distance and act at extrasynaptic DA receptors and transporters outside active zones, even in conventional neuronal circuits of the basal ganglia. It is likely that DA receptors in the SEZ act as striatal receptors and that DA action and reuptake occur when diffusing molecules encounter cell membranes or processes (Beaulieu and Gainetdinov, 2011).

Adult neurogenesis is presently the only endogenous neuronal replacement mechanism; therefore, increasing the knowledge about signaling within the SEZ microenvironment could be fundamental to develop strategies aimed at promoting intrinsic repair by endogenous progenitors (i.e., in neurodegenerative diseases). Genomic ${ }^{14} \mathrm{C}$ level-based retrospective birth dating analysis in postmortem human brains has indicated that NSCs in the adult human SEZ do not longer contribute new neurons for the $\mathrm{OB}$, but they do generate new neurons for the striatum (Ernst et al., 2014). Interestingly, parkinsonian deficits are most relevant in basal ganglia adjacent to the SEZ neurogenic niche; therefore, restoration by endogenous progenitors emerges as an exciting possibility, especially if a potential to generate striatal neurons is ultimately corroborated. On the other hand, postnatal neurogenesis offers a way to understand the role of proteins, such as $\alpha$-SYN, on different stages of neuronal development in adult individuals.

\section{References}

Abeliovich A, Schmitz Y, Fariñas I, Choi-Lundberg D, Ho WH, Castillo PE, Shinsky N, Verdugo JM, Armanini M, Ryan A, Hynes M, Phillips H, Sulzer D, Rosenthal A (2000) Mice lacking alpha-synuclein display functional deficits in the nigrostriatal dopamine system. Neuron 25:239252. CrossRef Medline

Al-Wandi A, Ninkina N, Millership S, Williamson SJ, Jones PA, Buchman VL (2010) Absence of alpha-synuclein affects dopamine metabolism and synaptic markers in the striatum of aging mice. Neurobiol Aging 31:796804. CrossRef Medline

Aponso PM, Faull RL, Connor B (2008) Increased progenitor cell proliferation and astrogenesis in the partial progressive 6-hydroxydopamine model of Parkinson's disease. Neuroscience 151:1142-1153. CrossRef Medline

Baker H, Morel K, Stone DM, Maruniak JA (1993) Adult naris closure profoundly reduces tyrosine hydroxylase expression in mouse olfactory bulb. Brain Res 614:109-116. CrossRef Medline

Barnett SA, Smart JL (1975) The movements of wild and domestic house mice in an artificial environment. Behav Biol 15:85-93. CrossRef Medline

Beaulieu JM, Gainetdinov RR (2011) The physiology, signaling, and pharmacology of dopamine receptors. Pharmacol Rev 63:182-217. CrossRef Medline

Berg DA, Belnoue L, Song H, Simon A (2013) Neurotransmitter-mediated control of neurogenesis in the adult vertebrate brain. Development 140: 2548-2561. CrossRef Medline

Bjornsson CS, Apostolopoulou M, Tian Y, Temple S (2015) It takes a village: constructing the neurogenic niche. Dev Cell 32:435-446. CrossRef Medline
Bouab M, Paliouras GN, Aumont A, Forest-Bérard K, Fernandes KJ (2011) Aging of the subventricular zone neural stem cell niche: evidence for quiescence-associated changes between early and mid-adulthood. Neuroscience 173:135-149. CrossRef Medline

Burré J (2015) The synaptic function of alpha-synuclein. J Parkinsons Dis 5:699-713. CrossRef Medline

Chaker Z, Codega P, Doetsch F (2016) A mosaic world: puzzles revealed by adult neural stem cell heterogeneity. Wiley Interdiscip Rev Dev Biol 5:640-658. CrossRef Medline

Cheng F, Vivacqua G, Yu S (2011) The role of alpha-synuclein in neurotransmission and synaptic plasticity. J Chem Neuroanat 42:242-248. CrossRef Medline

Codega P, Silva-Vargas V, Paul A, Maldonado-Soto AR, Deleo AM, Pastrana E, Doetsch F (2014) Prospective identification and purification of quiescent adult neural stem cells from their in vivo niche. Neuron 82:545559. CrossRef Medline

Connor-Robson N, Peters OM, Millership S, Ninkina N, Buchman VL (2016) Combinational losses of synucleins reveal their differential requirements for compensating age-dependent alterations in motor behavior and dopamine metabolism. Neurobiol Aging 46:107-112. CrossRef Medline

Coronas V, Bantubungi K, Fombonne J, Krantic S, Schiffmann SN, Roger M (2004) Dopamine D3 receptor stimulation promotes the proliferation of cells derived from the post-natal subventricular zone. J Neurochem 91: 1292-1301. CrossRef Medline

Enwere E, Shingo T, Gregg C, Fujikawa H, Ohta S, Weiss S (2004) Aging results in reduced epidermal growth factor receptor signaling, diminished olfactory neurogenesis, and deficits in fine olfactory discrimination. J Neurosci 24:8354-8365. CrossRef Medline

Ernst A, Alkass K, Bernard S, Salehpour M, Perl S, Tisdale J, Possnert G, Druid H, Frisén J (2014) Neurogenesis in the striatum of the adult human brain. Cell 156:1072-1083. CrossRef Medline

Fanselow MS (1980) Conditioned and unconditional components of postshock freezing. Pavlov J Biol Sci 15:177-182. Medline

Freundlieb N, François C, Tandé D, Oertel WH, Hirsch EC, Höglinger GU (2006) Dopaminergic substantia nigra neurons project topographically organized to the subventricular zone and stimulate precursor cell proliferation in aged primates. J Neurosci 26:2321-2325. CrossRef Medline

Höglinger GU, Rizk P, Muriel MP, Duyckaerts C, Oertel WH, Caille I, Hirsch EC (2004) Dopamine depletion impairs precursor cell proliferation in Parkinson disease. Nat Neurosci 7:726-735. CrossRef Medline

Höglinger GU, Arias-Carrión O, Ipach B, Oertel WH (2014) Origin of the dopaminergic innervation of adult neurogenic areas. J Comp Neurol 522: 2336-2348. CrossRef Medline

Huisman E, Uylings HB, Hoogland PV (2004) A 100\% increase of dopaminergic cells in the olfactory bulb may explain hyposmia in Parkinson's disease. Mov Disord 19:687-692. CrossRef Medline

Kim Y, Wang WZ, Comte I, Pastrana E, Tran PB, Brown J, Miller RJ, Doetsch F, Molnár Z, Szele FG (2010) Dopamine stimulation of postnatal murine subventricular zone neurogenesis via the $\mathrm{D} 3$ receptor. J Neurochem 114:750-760. CrossRef Medline

Kippin TE, Kapur S, van der Kooy D (2005) Dopamine specifically inhibits forebrain neural stem cell proliferation, suggesting a novel effect of antipsychotic drugs. J Neurosci 15:5815-5823. CrossRef Medline

Lao CL, Lu CS, Chen JC (2013) Dopamine D3 receptor activation promotes neural stem/progenitor cell proliferation through AKT and ERK1/2 pathways and expands type- $\mathrm{B}$ and $-\mathrm{C}$ cells in adult subventricular zone. Glia 61:475-489. CrossRef Medline

Lennington JB, Pope S, Goodheart AE, Drozdowicz L, Daniels SB, Salamone JD, Conover JC (2011) Midbrain dopamine neurons associated with reward processing innervate the neurogenic subventricular zone. J Neurosci 31:13078-13087. CrossRef Medline

Liu BF, Gao EJ, Zeng XZ, Ji M, Cai Q, Lu Q, Yang H, Xu QY (2006) Proliferation of neural precursors in the subventricular zone after chemical lesions of the nigrostriatal pathway in rat brain. Brain Res 1106:30-39. CrossRef Medline

Lledo PM, Valley M (2016) Adult olfactory bulb neurogenesis. Cold Spring Harb Perspect Biol 8:a018945. CrossRef Medline

Llorens-Bobadilla E, Zhao S, Baser A, Saiz-Castro G, Zwadlo K, MartinVillalba A (2015) Single-cell transcriptomics reveals a population of dormant neural stem cells that become activated upon brain injury. Cell Stem Cell 17:329-340. CrossRef Medline 
Lou X, Kim J, Hawk BJ, Shin YK (2017) $\alpha$-Synuclein may cross-bridge $\mathrm{v}$-SNARE and acidic phospholipids to facilitate SNARE-dependent vesicle docking. Biochem J 474:2039-2049. CrossRef Medline

Luo J, Daniels SB, Lennington JB, Notti RQ, Conover JC (2006) The aging neurogenic subventricular zone. Aging Cell 5:139-152. CrossRef Medline

Marxreiter F, Nuber S, Kandasamy M, Klucken J, Aigner R, Burgmayer R, Couillard-Despres S, Riess O, Winkler J, Winner B (2009) Changes in adult olfactory bulb neurogenesis in mice expressing the A30P mutant form of alpha-synuclein. Eur J Neurosci 29:879-890. CrossRef Medline

Marxreiter F, Regensburger M, Winkler J (2013) Adult neurogenesis in Parkinson's disease. Cell Mol Life Sci 70:459-473. CrossRef Medline

Maslov AY, Barone TA, Plunkett RJ, Pruitt SC (2004) Neural stem cell detection, characterization, and age-related changes in the subventricular zone of mice. J Neurosci 24:1726-1733. CrossRef Medline

Mich JK, Signer RA, Nakada D, Pineda A, Burgess RJ, Vue TY, Johnson JE, Morrison SJ (2014) Prospective identification of functionally distinct stem cells and neurosphere-initiating cells in adult mouse forebrain. Elife 3:e02669. CrossRef Medline

Milanovic S, Radulovic J, Laban O, Stiedl O, Henn F, Spiess J (1998) Production of the Fos protein after contextual fear conditioning of C57BL/6N mice. Brain Res 784:37-47. CrossRef Medline

Mirzadeh Z, Merkle FT, Soriano-Navarro M, Garcia-Verdugo JM, AlvarezBuylla A (2008) Neural stem cells confer unique pinwheel architecture to the ventricular surface in neurogenic regions of the adult brain. Cell Stem Cell 3:265-278. CrossRef Medline

Muñoz-Manchado AB, Villadiego J, Suárez-Luna N, Bermejo-Navas A, Garrido-Gil P, Labandeira-García JL, Echevarría M, López-Barneo J, Toledo-Aral JJ (2013) Neuroprotective and reparative effects of carotid body grafts in a chronic MPTP model of Parkinson's disease. Neurobiol Aging 34:902-915. CrossRef Medline

Nuber S, Petrasch-Parwez E, Winner B, Winkler J, von Hörsten S, Schmidt T, Boy J, Kuhn M, Nguyen HP, Teismann P, Schulz JB, Neumann M, Pichler BJ, Reischl G, Holzmann C, Schmitt I, Bornemann A, Kuhn W, Zimmermann F, Servadio A, et al. (2008) Neurodegeneration and motor dysfunction in a conditional model of Parkinson's disease. J Neurosci 28: 2471-2484. CrossRef Medline

Obeso JA, Rodriguez-Oroz MC, Stamelou M, Bhatia KP, Burn DJ (2014) The expanding universe of disorders of the basal ganglia. Lancet 384:523531. CrossRef Medline

O'Keeffe GC, Tyers P, Aarsland D, Dalley JW, Barker RA, Caldwell MA (2009) Dopamine-induced proliferation of adult neural precursor cells in the mammalian subventricular zone is mediated through EGF. Proc Natl Acad Sci U S A 106:8754-8759. CrossRef Medline

Park JH, Enikolopov G (2010) Transient elevation of adult hippocampal neurogenesis after dopamine depletion. Exp Neurol 222:267-276. CrossRef Medline

Pellow S, Chopin P, File SE, Briley M (1985) Validation of open:closed arm entries in an elevated plus-maze as a measure of anxiety in the rat. J Neurosci Methods 14:149-167. CrossRef Medline

Peña-Oliver Y, Buchman VL, Stephens DN (2010) Lack of involvement of alpha-synuclein in unconditioned anxiety in mice. Behav Brain Res 209: 234-240. CrossRef Medline

Peña-Oliver Y, Buchman VL, Dalley JW, Robbins TW, Schumann G, Ripley TL, King SL, Stephens DN (2012) Deletion of alpha-synuclein decreases impulsivity in mice. Genes Brain Behav 11:137-146. CrossRef Medline

Peña-Oliver Y, Sanchez-Roige S, Stephens DN, Ripley TL (2014) Alphasynuclein deletion decreases motor impulsivity but does not affect risky decision making in a mouse Gambling Task. Psychopharmacology (Berl) 231:2493-2506. CrossRef Medline

Peng J, Andersen JK (2011) Mutant alpha-synuclein and aging reduce neurogenesis in the acute 1-methyl-4-phenyl-1,2,3,6-tetrahydropyridine model of Parkinson's disease. Aging Cell 10:255-262. CrossRef Medline
Perez-Villalba A, Palop MJ, Pérez-Sánchez F, Fariñas I (2015) Assessment of olfactory behavior in mice: odorant detection and habituation-dishabituation tests. Bio-protocol 5:e1518. CrossRef

Poewe W, Seppi K, Tanner CM, Halliday GM, Brundin P, Volkmann J, Schrag AE, Lang AE (2017) Parkinson disease. Nat Rev Dis Primers 3:17013. CrossRef Medline

Raponi E, Agenes F, Delphin C, Assard N, Baudier J, Legraverend C, Deloulme JC (2007) S100B expression defines a state in which GFAPexpressing cells lose their neural stem cell potential and acquire a more mature developmental stage. Glia 55:165-177. CrossRef Medline

Recasens A, Dehay B, Bové J, Carballo-Carbajal I, Dovero S, Pérez-Villalba A, Fernagut PO, Blesa J, Parent A, Perier C, Fariñas I, Obeso JA, Bezard E, Vila M (2014) Lewy body extracts from Parkinson disease brains trigger alpha-synuclein pathology and neurodegeneration in mice and monkeys. Ann Neurol 75:351-362. CrossRef Medline

Rey NL, Sacquet J, Veyrac A, Jourdan F, Didier A (2012) Behavioral and cellular markers of olfactory aging and their response to enrichment. Neurobiol Aging 33:626.e9-626.e23. CrossRef Medline

Schlachetzki JC, Grimm T, Schlachetzki Z, Ben Abdallah NM, Ettle B, Vöhringer P, Ferger B, Winner B, Nuber S, Winkler J (2016) Dopaminergic lesioning impairs adult hippocampal neurogenesis by distinct modification of alpha-synuclein. J Neurosci Res 94:62-73. CrossRef Medline

Tramontin AD, García-Verdugo JM, Lim DA, Alvarez-Buylla A (2003) Postnatal development of radial glia and the ventricular zone (VZ): a continuum of the neural stem cell compartment. Cereb Cortex 13:580 587. CrossRef Medline

Van Kampen JM, Hagg T, Robertson HA (2004) Induction of neurogenesis in the adult rat subventricular zone and neostriatum following dopamine D3 receptor stimulation. Eur J Neurosci 19:2377-2387. CrossRef Medline

Venda LL, Cragg SJ, Buchman VL, Wade-Martins R (2010) $\alpha$-Synuclein and dopamine at the crossroads of Parkinson's disease. Trends Neurosci 33:559-568. CrossRef Medline

Winner B, Winkler J (2015) Adult neurogenesis in neurodegenerative diseases. Cold Spring Harb Perspect Biol 7:a021287. CrossRef Medline

Winner B, Lie DC, Rockenstein E, Aigner R, Aigner L, Masliah E, Kuhn HG, Winkler J (2004) Human wild-type alpha-synuclein impairs neurogenesis. J Neuropathol Exp Neurol 63:1155-1166. CrossRef Medline

Winner B, Geyer M, Couillard-Despres S, Aigner R, Bogdahn U, Aigner L, Kuhn G, Winkler J (2006) Striatal deafferentation increases dopaminergic neurogenesis in the adult olfactory bulb. Exp Neurol 197:113121. CrossRef Medline

Winner B, Rockenstein E, Lie DC, Aigner R, Mante M, Bogdahn U, CouillardDespres S, Masliah E, Winkler J (2008) Mutant alpha-synuclein exacerbates age-related decrease of neurogenesis. Neurobiol Aging 29:913-925. CrossRef Medline

Winner B, Desplats P, Hagl C, Klucken J, Aigner R, Ploetz S, Laemke J, Karl A, Aigner L, Masliah E, Buerger E, Winkler J (2009) Dopamine receptor activation promotes adult neurogenesis in an acute Parkinson model. Exp Neurol 219:543-552. CrossRef Medline

Winner B, Regensburger M, Schreglmann S, Boyer L, Prots I, Rockenstein E, Mante M, Zhao C, Winkler J, Masliah E, Gage FH (2012) Role of alphasynuclein in adult neurogenesis and neuronal maturation in the dentate gyrus. J Neurosci 32:16906-16916. CrossRef Medline

Yamada M, Onodera M, Mizuno Y, Mochizuki H (2004) Neurogenesis in olfactory bulb identified by retroviral labeling in normal and 1-methyl-4phenyl-1,2,3,6-tetrahydropyridine-treated adult mice. Neuroscience 124: 173-181. CrossRef Medline

Zhong SC, Luo X, Chen XS, Cai QY, Liu J, Chen XH, Yao ZX (2010) Expression and subcellular location of alpha-synuclein during mouse-embryonic development. Cell Mol Neurobiol 30:469-482. CrossRef Medline 